\title{
Dolaylı ve Dolaysız Vergiler ile Ekonomik Büyüme Arasındaki Nedensellik iliş̧kisi: Türkiye Örneği (2006-2018) ${ }^{1}$
}

\section{The Casuality Relationship Among Direct Taxes, Indirect Taxes and Economic Growth: The Case of Turkey (2006-2018)}

\author{
Ersin Nail Sağdıç \\ Duygu Aydın**
}

RESEARCH

ARTICLE

\section{ARTICLE INFO}

Submitted : 27.12.2020

Revised : 21.06 .2021

Accepted : 29.06.2021

Available : 30.06.2021

iThenticate similarity

score: $13 \%$

JEL classification:

$\mathrm{H} 2 \mathrm{O}, \mathrm{H} 24, \mathrm{H} 27$

Keywords:

Economic Growth, Indirect Taxes, Direct Taxes

\begin{abstract}
A B S T R A C T
In this study, the relationship between the direct and indirect taxes and economic growth between the years 2006-2018 including the provinces in Turkey was investigated by panel data analysis. After investigating the cross-section dependence and stationarity levels of the variables, longterm relationship between the variables was determined by the Westerlund and Edgerton LM Bootstrap Cointegration Test (2007). The causality relationship between the variables was determined by the Panel VECM Causality Test. The results of the present study show that there is a long-term relationship between the direct and indirect taxes and economic growth between the years 2006-2018 in Turkey. it was determined that there is a one-way causality relationship from direct taxes to economic growth both in the long and short term. Moreover, it was put forward that there is a one way causality relationship from indirect taxes to economic growth in the short term while there is a two way causal relationship between economic growth and indirect taxes in the long term.
\end{abstract}

Cite this article as: Sağdıç, E.N. \& Aydın, D. (2021). “Dolaylı ve Dolaysız Vergiler ile Ekonomik Büyüme Arasındaki Nedensellik İlişkisi: Türkiye Örneği (2006-2018)", International Journal of Public Finance, 6(1), 21-46.

1 Bu çalışma Kütahya Dumlupınar Üniversitesi Lisansüstü Eğitim Enstitüsü Maliye Anabilim Dalı'nda 08.07.2020 tarihinde savunulan ve jüri tarafından kabul edilen “Türkiye'de Dolaylı ve Dolaysız Vergiler ile Ekonomik Büyüme Arasındaki Nedensellik İlişkisi (2006-2018)" adlı yüksek lisans tezinden türetilmiştir.

* Assist. Prof. PhD., Kütahya Dumlupınar University, Department of Public Finance, Turkey, ORCID: 0000-0002-4022-8515, ersinnailsagdic@dpu.edu.tr

** Master Student and Assistant Revenue Specialist of Bursa Tax Administration Presidency, Turkey, ORCID: 0000-0001-9108-4163, duyguaydnnn@gmail.com 
Sağdıç, E.N. \& Aydın, D. (2021). “Dolaylı ve Dolaysız Vergiler ile Ekonomik Büyüme Arasındaki Nedensellik İlişkisi: Türkiye Örneği (2006-2018)”, International Journal of Public Finance, 6(1), 21-46.

\begin{tabular}{|c|c|}
\hline MAKALE BİLGisi & Ö Z \\
\hline Gönderme: 27.12.2020 & \multirow{8}{*}{$\begin{array}{l}\text { Bu çalışmada, Türkiye'de } 2006-2018 \text { yılları arasında iller bazında dolaylı ve } \\
\text { dolaysız vergiler ile ekonomik büyüme arasındaki ilişki panel veri analizi ile } \\
\text { araştırılmıştır. Değişkenlerin yatay kesit bağımlııkları ve durağanlık } \\
\text { seviyeleri araştırılarak değişkenler arasındaki uzun dönemli eşbütünleşik } \\
\text { ilişki Westerlund ve Edgerton LM Bootstrap Eşbütünleşme (2007) testi ile, } \\
\text { nedensellik ilişkisi ise Panel VECM Nedensellik Testi ile tespit edilmiştir. } \\
\text { Araştırma sonuçları, Türkiye'de 2006-2018 yılları arasında dolaylı ve } \\
\text { dolaysız vergiler ile ekonomik büyüme arasında uzun dönemli ilişki } \\
\text { olduğunu ortaya koymaktadır. Bunun yanında nedensellik test sonuçları } \\
\text { hem uzun hem de kısa dönemde dolaysız vergilerden ekonomik büyümeye } \\
\text { doğru tek yönlü nedensellik olduğunu göstermektedir. Ayrıca dolaylı } \\
\text { vergilerden ekonomik büyümeye doğru kısa dönemde tek yönlü } \\
\text { nedensellik olduğu belirlenirken uzun dönemde ekonomik büyüme ve } \\
\text { dolaylı vergiler arasında çift yönlü nedensellik ilişkisi olduğu tespit } \\
\text { edilmiştir. }\end{array}$} \\
\hline Düzeltme : 21.06.2021 & \\
\hline : 29.06.2021 & \\
\hline Yayın $\quad: 30.06 .2021$ & \\
\hline $\begin{array}{l}\text { iThenticate benzerlik } \\
\text { oranı: } \% 13\end{array}$ & \\
\hline $\begin{array}{l}\text { JEL Kodu: } \\
\mathrm{H} 20, \mathrm{H} 24, \mathrm{H} 27\end{array}$ & \\
\hline Anahtar Kelimeler: & \\
\hline $\begin{array}{l}\text { Dolaylı Vergiler, } \\
\text { Dolaysız Vergiler, } \\
\text { Ekonomik Büyüme }\end{array}$ & \\
\hline
\end{tabular}

\section{Giriş}

Vergiler temel olarak kamusal hizmetlerin finansmanı için alınan kamu geliridir. Gelişmiş ve gelişmekte olan ülkelerde vergiler sadece kamusal malların finansmanını sağlamak için değil, aynı zamanda gelir-servet dağılımında adaleti sağlamak, kaynakların etkin dağııımını gerçekleştirmek, ekonomik istikrarı sağlamak, büyüme ve kalkınmayı sağlamak gibi ekonomik ve sosyal amaçlara yönelik de alınmaktadır. Bu amaçlar arasında ekonomik büyüme ve kalkınmanın sağlanması birçok gelişmekte olan ülkede önem arz ettiğinden vergi politikaları da önemli hale gelmiştir. Diğer taraftan vergilerin ekonomi politikalarında bir araç olarak kullanılmasının yanı sıra, ekonomik değişkenlerin neredeyse tamamından etkilenmesi vergi politikalarının etkin olarak uygulanabilmesi sorununu ortaya çıkarmıştır.

Vergiler ve ekonomik büyüme birbirini etkileyen iki temel iktisadi olgudur. Hem vergilerin ekonomik büyümeyi olumlu ve olumsuz etkileyebileceği hem de ekonomik büyümenin vergileri olumlu ve olumsuz etkileyebileceği birçok çalışma tarafından ortaya konulmaktadır. Vergilerin ekonomik büyüme üzerindeki etkileri, verginin türü, vergi sistemlerinin yapısı, verginin tahsil edilme şekli vb. gibi unsurlara bağlı olarak farklılık göstermektedir. Örneğin literatürdeki çalışmalara bakıldığında dolaysız vergilerin indirim, teşvik, denetim araçları yoluyla ekonomik büyümeyi olumlu etkileyebileceği, dolaylı vergilerin ise tüketimleri azaltarak tasarrufları ve dolayısıyla yatırımları artırarak ekonomik büyümeyi artırabileceği ifade edilebilir. Benzer şekilde ekonomik büyümenin nasıl gerçekleştiği, büyümede kullanılan kaynaklar ve üretim faktörlerinin çeşitliliği, ölçek ekonomileri, sermaye ve emeğin faktör verimlilikleri ve bileşimleri, yatırımların ve tasarrufların yapısı vb. gibi bir çok faktöre bağlı olarak ekonomik büyümenin vergiler üzerinde doğrudan ve dolaylı etkide bulunabileceği açık bir şekilde belirtilebilir. Ülkelerin vergi yapılarında oluşan değişimlerin ekonomik büyüme üzerinde nasıl bir etki yarattığı uygulanan politikaların etkinliği açısından önemlidir. Bu sayede uygulanan vergi politikaları ve ekonomik büyüme arasındaki ilişki 
belirlenmektedir. Benzer şekilde ülkelerin en büyük finansman kaynağı olan vergilerin de ekonomik büyümeden nasıl etkilendiğini tespit etmek ve buna bağlı olarak politikalar geliştirmek önem arz etmektedir. Buradan yola çıkılarak bu çalışmada Türkiye'de 2006-2018 dönemini baz alarak iller düzeyinde dolaylı ve dolaysız vergiler ile ekonomik büyüme arasındaki uzun dönemli ilişkinin varlığı ve değişkenler arasındaki nedensellik ilişkisinin panel veri analizi yöntemiyle incelenmesi hedeflenmiştir. Bu çalışma literatüre bir çok yönden katkıda bulunmaktadır. Öncelikle çalışma dolaylı ve dolaysız vergilerin ekonomik büyüme üzerindeki etkilerini bölgesel düzeyde tespit etmesi açısından önem arz etmektedir. Bunun yanında bölgesel düzeyde değişkenler arasındaki uzun ve kısa dönemli nedensellik sonuçları ekonomik büyüme politikalarında vergilerin bölgesel düzeyde etkilerini göstermesi açısından ayrıca önem arz etmektedir. Ayrıca ekonomik büyüme ve vergiler arasındaki teorik ilişkinin iktisadi görüşler ve büyüme modelleri temelinde geniş bir şekilde ele alınması çalışmayı literatürdeki diğer çalışmalardan ayırmaktadır.

Çalışma giriş bölümü ile beş bölüm olarak dizayn edilmiştir. Giriş bölümünü takip eden ikinci bölümde ekonomik büyüme ve vergiler arasındaki teorik ilişki incelenmiştir. Üçüncü bölüm ekonomik büyüme ve vergiler arasındaki ilişkiyi inceleyen ampirik çalışmaların özetlendiği literatür kısmından oluşmaktadır. Dördüncü bölüm, oluşturulan modeller, metodoloji ve ampirik bulguları özetlenmektedir. Sonuç bölümünde ise araştırmanın ortaya koyduğu ampirik bulgular değerlendirilerek çıkarımlarda bulunulmuştur.

\section{Vergiler ve Ekonomik Büyüme Arasındaki Teorik ilişski}

Ekonomik büyüme, bir ülkedeki üretilen mal ve hizmetlerin niceliksel olarak artması şeklinde tanımlanabilir. Aynı zamanda ekonomik büyüme kişi başına düşen gelir düzeyinin reel olarak artmasıdır. Ekonomik büyüme ya tam istihdam seviyesi altındaki kaynakların etkin ve verimli olarak kullanılmasıyla ya da mevcut kaynaklara yeni kaynakların eklenmesiyle ortaya çıkmaktadır. Ekonomik büyüme için kullanılan temel faktörler üretim faktörleridir. Bu faktörler; emek, sermaye, teknolojik gelişmeler, doğal kaynaklar ve girişimciliktir. Ekonomik büyüme fonksiyonu içerisine bu faktörler, fiziki sermaye, beşerî sermaye, doğal kaynaklar ve teknolojik gelişmeler olarak dâhil edilmektedir. Söz konusu faktörlerdeki artış ya da verimliliğin sağlanması ekonomik büyümeyi de doğal olarak artırmaktadır. Ekonomik büyümenin nasıl sağlanacağı aynı zamanda birçok iktisatçı tarafından da teorik olarak ele alınmıştır. Bu teoriler, Klasik Büyüme Teorileri, Harrod-Domar Büyüme Teorisi, Neo-Klasik Büyüme Teorisi ve İçsel Büyüme Teorisi'dir. Ekonomik büyüme teorileri genel olarak, ekonomik büyümenin uzmanlaşma, iş bölümü, sermeye birikimi, teknolojik gelişmeler, kamu-özel tasarrufların artırılması, atıl tasarrufların yatırıma dönüştürülmesi, yatırım seviyelerinin artırılması, ar-ge faaliyetlerinin artırılması, beşeri sermaye yatırımlarının artırılması (eğitim, sağlık, kültürel vb. gibi), beşeri sermaye verimliliğin artırılması ve kamu politikalarıyla üretimin desteklenmesi gibi bir çok ekonomik alt değişkene bağlı olarak artırılabileceğini öne sürmektedir. Vergilerin etkinliği Neo-klasik büyüme teorileri kapsamında ele alınmıştır. Neo klasik büyüme teorisi, vergilerin uzun vadede üretim 
üzerinde etkili olmayacağı görüşünü savunmaktadır. Benzer şekilde içsel büyüme teorisinde de vergilerin ekonomik büyümenin hızını yavaşlatacağı görüşü hakimdir. Örneğin içsel büyüme teorilerinde, gelir ve servet vergileri, tasarruflar ve yatırımları azaltması nedeniyle bozucu vergiler olarak adlandırılmıştır. Harcama vergileri ise sadece tüketim seviyesini etkileyen bozucu olmayan vergiler olarak adlandırılmıştır. Sonuç olarak içsel büyüme modellerinde dolaysız vergiler ekonomi üzerinde olumsuz etkili, dolaylı vergiler ise nötr etkili varsayılmıştır. Bu nedenle içsel büyüme modellerinde vergilerin ekonomik büyüme üzerinde etkili oldukları belirtilebilir. Harrod-Domar Büyüme Teorisi'nde de vergiler yatırımı artıran bir araç olarak varsayılmıştır (Demircan, 2003: 98-99).

Ekonomik büyüme teorileri ve vergilerin ekonomik büyüme üzerindeki etkilerine yönelik çalışmaların başında Robert Solow tarafından ortaya koyulan NeoKlasik Büyüme Teorisi gelmektedir. Neo-Klasik Büyüme Modeli teknolojiyi dışsal bir faktör olarak kabul etmekte ve bazı temel varsayımlara dayanmaktadır. Bunlar; ölçeğe göre getirilerin sabit olması, sermayenin marjinal verimliliğin azalması, faktörler arasında ikamenin mümkün olması ve yatırım-tasarruf eşitliğidir (Kibritçioğlu, 1998: 8). Teknolojik dışsallığa dayanan Neo-Klasik modelin, teknolojinin dışsallık yoluyla sermayenin marjinal verimliliğindeki azalmaları telafi edeceği varsayılmaktadır. Bu model, teknoloji düzeylerinin tüm ülkelerde sabit olduğu varsayımı altında, gelişmiş ve gelişmekte olan ülkelerin uzun dönem büyüme oranlarının birbirlerini yakalayacağını belirtmektedir. Yakınlaşma hipotezi olarak bilinen bu durum gelişmiş ülkelerden sermayenin getirisinin yüksek olduğu gelişmekte olan ülkelere sermaye akışı ile gerçekleşmektedir (Kibritçioğlu, 1998:8). Barro (1991)'e göre bu yakınlaşma durumu "koşullu yakınlaşma" olarak ifade edilmiştir. Buna göre teknolojinin dışsal ve sabit olduğu varsayımının gerçekçi olmadığı, sermaye transferlerinin yakınlaştırıcı etkisinin gelişmiş ülkelerdeki teknolojik gelişmeler ile bertaraf edilebileceği varsayılmıştır. Benzer şekilde Romer (1994) ve Lucas (1988)'in yapmış olduğu çalışmalarda ekonomik büyümedeki gelişmelerin sermaye ve işgücü miktarındaki artıştan ziyade teknolojik gelişme ile elde edildiği varsayılmıştır. Bu modellere beşeri sermaye, nüfus, ar-ge yatırımları, teknolojik gelişmeler ve maliye politikaları dahil edilerek - içsel- içsel büyüme teorisi geliştirilmiştir. Vergiler açısından düşünüldüğünde içsel büyüme teorilerindeki modele dahil edilen maliye politikaları ile vergi oranlarındaki değişikliklerin yatırımları ve dolayısıyla ekonomik büyümeyi etkileyeceği varsayılmaktadır (Kibritçioğlu, 1998: 13). Her iki modelde de maliye politikaları aracılığıyla vergilerin ekonomik büyüme üzerinde etkili olduğu belirtilebilir. Fakat bu hususta da görüş ayrılıkları mevcuttur. Vergiler açısından bakıldığında her iki modelde vergilerin ekonomik büyümeyi kısa dönemde etkileyeceği, fakat vergilerin ekonomik büyüme üzerinde uzun dönemde etkisinin olmayacağı varsayılmaktadır. Uzun dönemde ise, Neo-klasik Büyüme Modeli'nde vergilerin ekonomik büyüme üzerinde etkisinin olmadığı, içsel büyüme modellerinde de bu etkinin kısıtlı ve yavaş olduğu görüşü hakimdir. Büyüme hızının sermaye birikimi ile sağlandığı ve Keynesyen varsayıma dayanan Harrod-Domar Büyüme Modeli'nde, kamu yatırımları, vergi gibi maliye politikası araçları kullanılarak ekonomik büyüme gerçekleştirilmeye çalışılmaktadır (Demircan, 2003: 98). Bu durumda kamu yatırımları ekonomik 
kalkınmanın dinamiği, vergiler ise tasarruflar aracılığıyla yatırım ve gelir artırıcı bir araç olarak kabul edilmiştir.

Vergi gelirleri ve ekonomik büyüme ekonomide birbirini etkileyen iki temel iktisadi olgudur. Vergiler ile ekonomik büyüme arasındaki temel ilişki ekonomik büyüme üzerinden değerlendirildiğinde, ekonomik büyümedeki artışın gelir seviyesinin artıracağı böylelikle vergi tabanının genişleyerek vergilerin de artacağı şeklindedir. Daha açık bir ifadeyle ekonomik büyümeyi etkileyen tüm faktörler vergi gelirlerini etkileyecektir. Ekonomik büyüme ve ekonomik büyümeyi etkileyen faktörler arttığında öncelikle ekonomide vergi tabanı genişleyecektir (Gupta, 2007: 4; Sağdıç, 2019:157). $\mathrm{Bu}$ yönüyle ele alındığında fiziki ve beşeri sermayenin gelişmesi, teknolojik yenilikler, atıl tasarrufların yatırıma dönüştürülmesi, tüketim düzeylerinin artması, ar-ge faaliyetlerinin artması, firma gelirlerinin artması gibi birçok faktör doğal olarak vergi gelirlerini artıracaktır. Buradaki önemli olan husus ekonomik büyüme ile vergi tabanının ve dolayısıyla vergi gelirlerinin artmasıdır. Ekonomik büyümenin vergiler üzerindeki diğer etkisi ise Wagner Kanunu ile ortaya çıkmaktadır. Wagner Kanunu'na göre ekonomik büyüme ile kişilerin gelirlerinde meydana gelen artış kamusal mal ve hizmetlere olan talep seviyesini de artıracaktır. Bu durumda kamusal mal ve hizmetlere olan talep artışı kamu harcamalarını da artıracak ve artan kamu harcamalarının finansmanı da yine vergilerle finanse edilecek ve bu sayede vergi gelirleri tekrar artacaktır (Gupta, 2007: 4; Sağdıç, 2019: 157).

Ekonomik büyüme ve vergi gelirleri arasındaki temel ilişkilerden bir diğeri ise ekonomik büyümenin vergi gelirleri üzerindeki olumsuz etkileridir. Gelişmekte olan ülkelerde ekonomik büyüme safhaları etkin ve verimli olarak gerçekleştirilemez ise kayıt dışı ekonominin artması, gelir ve servet dağılımındaki adaletsizliğin artması, kaynakların etkinsiz dağılması gibi birçok olumsuz etki meydana gelecektir. Örneğin vergi yapılarındaki dolaysız vergiler kayıt dışı ekonomiye neden olacaktır (Chaudhry \& Munir, 2010: 447; Sağdıç, 2019: 159). Zira kayıt dışı ekonomi başlı başına vergileri olumsuz yönde etkileyecektir. Gelir ve servet dağılımdaki adaletsizlikler, kaynakların belli bir kesim üzerinde kalması da vergi gelirlerini olumsuz etkileyecektir. Çünkü ekonomideki dinamiklerin büyük kısmını elinde bulunduran belirli kesimler (firmalar, baskı ve çıkar grupları vs.) muafiyet, istisna ve indirim gibi vergi harcamalarını kendi lehlerine doğru kullanacaklardır. Sonuç olarak vergi gelirleri olumsuz etkilenecektir.

Vergilerin ekonomik büyüme üzerindeki etkileri incelendiğinde, vergiler ilk olarak ekonomide yatırım, tasarruf ve tüketim kararlarını etkilemektedirler. Yatırım, tasarruf ve tüketim milli gelir fonksiyonunun temel bileşenleri olduğu için doğal olarak bu faktörlerde ekonomik büyümeyi etkilemektedir. Vergilerin ekonomik büyüme üzerindeki doğrudan etkisine bakıldığında, vergi oranlarında meydana gelen artışın toplam talepte azalmaya neden olarak ekonomik büyüme seviyesini düşürmesi olarak karşımıza çıkmaktadır. Vergi oranlarındaki azalış ise toplam talebi artırarak yatırımları etkileyecek ve dolayısıyla ekonomik büyüme artacaktır. Ya da vergi oranlarındaki artış bireylerin tasarruflarını artırarak yatırım vasıtasıyla ekonomik büyüme düzeyi artacaktır. Vergi oranlarındaki indirim durumunda ise, nispeten kullanılabilir gelir artacak, vergi tasarrufu sayesinde yatırımın maliyeti düşecek, yatırımların kârlılığı 
artacak, vergi için ayrılan fonlar serbest kalarak yatırıma finansman sağlanmış olacak ve yatırımların hacmini genişletecektir (Demircan, 2003: 105).

Vergilerin, bireylerin çalışma, tüketim, tasarruf ve yatırım tercihlerini direkt etkileme gücüne sahip olmalarından dolayı büyüme üzerinde farklı yollarla etkili olabilmektedir. Ekonomik büyüme ve vergiler arasındaki ilişkinin belirlenmesi uygulanacak vergi politikalarının şekillendirilmesinde fayda sağlayacaktır (Gül \& Kenar, 2009: 20). Vergilerin ekonomik büyüme üzerinde etkisi çok farklı yönlerden gerçekleşebilmektedir. Bunlardan ilki, vergilerin özel tüketimdeki artışı sınırlandırarak yatırımlar için zaruri olan tasarruf havuzunun büyümesini gerçekleştirmesidir. Diğeri ise, ülke kaynaklarının vergileme yoluyla özel sektörden kamu sektörüne aktarılmasıdır (Eshag, 1983: 90). Bu durumlarda vergiler ekonomik büyümeyi artıracaktır. Fakat vergi politikalarının etkin olarak ayarlanamadığı durumlarda vergilerden tasarruf yoluyla elde edilmesi beklenen ekonomik büyüme artışı tam tersine dönebilmektedir. Örneğin vergilerin artmasıyla firmaların nispeten gelirleri ve dolayısıyla yatırımları da düşmektedir. Bu durumdan ekonomik büyüme olumsuz etkilenecektir. Gelişmiş ülkelerde ekonomiye müdahale edilmeksizin ekonominin kendi iç dinamiği ile büyüme gerçekleştireceği kabul edilmiş olmasına karşın, gelişmekte olan ülkelerde sosyoekonomik yapının gelişmesi için dışarıdan bilinçli müdahalelere gerek duyulmaktadır. Bu nedenle uygulanacak kamu politikaları iktisadi büyüme ve gelişme üzerinde zaman ilerledikçe önem kazanmaktadır. Yine bu durumda da uygulanacak olan kamu politikalarının etkin olması gerekmektedir. Örneğin kamu tercihi teorisi perspektifinden ele alındığında, bu kaynakların etkin yatırımlara ve dolayısıyla milli gelir seviyesi üzerinde olumlu katkıda bulunmayacağı ifade edilebilir.

Vergilerin emek arzı üzerindeki etkileri de ekonomik büyüme açısından önem arz etmektedir. Çünkü vergilerin emek arzı üzerindeki etkisi direkt olarak ekonomik büyümeyi etkilemektedir. Vergilerin emek arzı üzerindeki iki temel etkisi vardır. Telafi etkisi olarak da bilinen bu etkiler gelir ve ikame etkisidir. Vergi oranları ve türlerindeki artışa bağlı olarak mükellefler vergiye karşı iki şekilde tepki vermektedirler. Bunlardan birisi, gelir etkisidir. Gelir etkisinde artan vergi oranları nedeniyle geliri azalan mükellefler daha çok çalışarak önceki gelir seviyesine ulaşmaya çalışmaktadırlar. Bu durumda mükellef emek arzını artırarak ekonomik büyümeye katkıda bulunacaktır. Mükelleflerin vergi oran ve türlerine verdiği ikinci tepki ikame etkisidir. İkame etkisinde vergilendirme sonrasında gelirleri azalan mükellefler boş zamanı çalışmaya ikame edeceklerdir. Bu durumda ise emek arzı olumsuz etkilenerek ekonomik büyüme de azalacaktır (Edizdoğan \& Çelikkaya, 2012: 20-28, Çelikay, 2018: 38-40). İkame etkisinde, vergiler arttıkça bireyler öncelikle tüketimlerini kısacaklardır. Ya da bireyler tasarruflarını vergi artışı öncesindeki seviyede tutmak isterlerse yine tüketimlerini kısarak bunu gerçekleştireceklerdir. Bu durumda ise ekonomik büyüme düzeyi azalmış olacaktır.

Ekonomik büyümeyi vergilerin türü ve alınma şekli gibi birçok faktör de etkilemektedir. Bu çalışmanın da temel çıkış noktasını oluşturan vergilerin dolaylı ve dolaysız olarak alınması ekonomik büyüme üzerinde farklı etkiler göstermektedir. Dolaysız vergiler genel olarak değerlendirildiğinde, tüketim ve tasarrufları ve dolaylı 
olarak ekonomik büyümeyi azaltmaktadır (Durkaya \& Ceylan, 2006: 81). Bireyler açısından değerlendirildiğinde, artan vergi oranına göre kişilerin nispeten gelirleri ve tasarrufları azalacaktır. Bunun yanında bireylerin yastık altı olarak tabir edilen atıl tasarruflara yönelmesine de neden olmaktadır. Her iki durumda da ekonomik büyüme tasarruf-yatırım ilişkisinden dolayı olumsuz etkilenecektir. Kurumlar açısından değerlendirildiğinde ise, vergi artışları kurumların yine nispeten gelirlerini ve kârlılıklarını azaltacaktır. Bu durumda kurumların yatırım yapma konusundaki istekleri azalacak ve böylelikle ekonomik büyüme olumsuz etkilenecektir (Uluatam, 2012: 389). Dolaysız vergilerden servet vergileri ise hem firmalar hem de bireylerin tasarruf eğilimlerini azaltmaktadır. Bu durumda sermaye birikimi azalmakta ve ekonomik büyüme olumsuz olarak etkilenmektedir.

Dolaylı vergiler de ekonomik büyümeyi etkilemektedir. Gelişmekte olan ülkelerde dolaylı vergiler içerisinde en yüksek oranla genellikle harcama vergileri yer almaktadır. Harcama vergileri öncelikle mal ve hizmet fiyatlarında değişikliğe yol açacak ve kaynakların etkinsiz dağılımına neden olacaktır. Bu yönüyle harcama vergileri ekonomik büyümeyi olumsuz etkileyecektir. Harcama vergilerindeki artış genellikle düşük gelir seviyesine sahip olan bireylerin tüketimini, yüksek gelir seviyesine sahip olan bireylerin ise tasarruflarının artmasına neden olmaktadır (Tümer, 2012: 76-77; Edizdoğan, 1981: 49-53). Bu açıdan harcama vergilerinin ekonomide genel olarak tasarruf artırıcı etkisi olduğu belirtilebilir. Diğer taraftan harcama vergilerindeki artış tüketimi azaltacağından ekonomide toplam talep düzeyinin azalmasına neden olmaktadır. Toplam talep düzeyinin azalması ise firmaların gelirlerini ve yatırım düzeylerini olumsuz etkileyecektir. $\mathrm{Bu}$ açıdan değerlendirildiğinde ise, harcama vergileri ekonomik büyümeyi olumsuz etkileyecektir. Fakat burada kişiler ve firmaların marjinal tasarruf ve tüketim eğilimleri önem arz etmektedir. Eğer vergi oranı artışında kişilerin marjinal tasarruf eğilimleri yüksekse vergi nedeniyle azalan tüketimlerini tasarrufa çevirebileceklerdir. Bu durumda da tasarrufların yatırıma dönüşeceği varsayımı altında ekonomik büyüme olumlu etkilenecektir. Vergiler ekonomik büyümeyi finansal piyasalar açısından da etkileyebilmektedir. Finansal piyasalar üzerindeki vergi yükü arttıkça para piyasalarındaki fonlar azalacak ve faiz oranları yükselecektir. Faiz oranlarının yükselmesiyle yatırım oranları azalacak ve milli gelir düzeyi azalacaktır (Durkaya \& Ceylan, 2006: 81). Bütün bu belirtilen ekonomik varsayımların yanında vergiler ve ekonomik büyüme arasındaki temel etkileşim vergi baskısı, vergi ahlakı, vergi kültürü, vergi uyumu gibi kavramlar açısından da önem arz etmektedir. Vergi oranlarının yüksek olduğu durumlarda bireylerin ve toplumların psikolojik ve sosyolojik olarak vergiye karşı vermiş oldukları tepkiler de vergileri olumsuz etkilemekte ve kayıt dışı ekonomi seviyesi aratarak ekonomik büyüme de olumsuz etkilenmektedir.

Vergilerin ekonomik büyüme üzerindeki etkileri de birçok yönden ele alınabilmektedir. Öncelikle vergiler açısından uygulanan para ve maliye politikaları ve iktisadi görüşlere ekonomik büyüme üzerinde etkili olmaktadır. Örneğin klasik iktisadi görüş çerçevesinde vergilerin ekonomik büyüme üzerindeki etkisinin nötr olduğu belirtilebilir. Bunun yanında arz yanlı iktisat görüşünde ise vergiler ekonomik büyüme üzerinde olumsuz bir etki yaratırken, tam tersine Keynesyen bir bakış açısıyla politika 
yürütmek, vergileri tamamen politika aracı haline getirmiş olmaktadır. íktisadi görüşlerinin temel amacının kaynakları en etkin biçimde kullanarak maksimumum çıktı düzeyini elde etmek olduğu düşünüldüğünde, vergiler bir politika aracı olduğundan ya da tamamen nötr olarak ele alındıklarından ekonomik büyümeyi olumlu veya olumsuz etkileyeceklerdir. Vergilerin ekonomik büyüme üzerinde meydana getirdiği etkiler iktisatçılar tarafından dikkat çeken konular arasında yer almıştır. Vergi gelirlerinin ekonomi üzerinde etkisinin olduğunu ilk kez vurgulayan İngiliz iktisatçı J.M. Keynes olmuştur. Keynesyen iktisat görüşünün öncesinde var olan Klasik iktisat teorisine göre tam rekabet piyasasında herhangi bir bozulma gerçekleştiğinde görünmez el sayesinde piyasa kendiliğinden denge noktasına gelecektir. Bu sebeple devlet ekonomiye müdahalede bulunmamalıdır (Ataç, 1997: 5-6). Klasik iktisada göre, her arz kendi talebini yaratmaktadır. Devlet ekonomiye müdahale etmemesi gerekmektedir. Devlet sadece güvenlik, adalet, savunma gibi temel görevleri yerine getirmeli, bütçe denk ve küçük olmalı, kamu borçlanması sadece olağanüstü dönemlerde söz konusu olmalıdır (Takım, 2011). Klasik iktisat görüşünde tarafsız devlet anlayışına göre kamu harcamalarının minimum seviyelerde olması gerekmektedir. Bu açıdan vergi gelirleri de minimum seviyelerde olması gerektiği görüşü öne çıkmaktadır. Adam Smith'in vergileme ilkelerindeki adalet, iktisadilik, uygunluk ve belirlilik ilkeleri de bu bakış açısıyla ele alınmıştır. Söz konusu ilkeler aracılığıyla devletin vergileri kesin ve net bir şekilde alması, adaletli olması, uygun zamanda alınması, maliyetinin düşük olması ve iktisadi davranışlar üzerinde etkisinin olmaması düşüncesi mevcuttur. Sonuç olarak klasik iktisat görüşüne göre vergiler devletin sadece adalet, diplomasi, güvenlik vb. gibi zorunlu ihtiyaçlarını karşılamak üzere aldığı düşük sevilerde olan bir kamu geliri olarak yorumlanabilir.

1929 yılında "Büyük Buhran" olarak adlandırılan krizin oraya çıkmasıyla Klasik iktisadi Düşüncenin savunduğu görüşler geçerliliğini kaybetmeye başlamıştır. Büyük krizle birlikte ekonominin eksik istihdamda olabileceği, her arzın kendi talebini yaratmadığı anlaşılmıştır. Gerçekleşen bu kriz sonrasında Keynesyen politikalarla devletin maliye politikası araçlarıyla ekonomiye müdahalede bulunması gerektiği ortaya çıkmaya başlamıştır. Keynesyen teoriye göre ekonomi istikrarsızdır. Kendi iç dinamikleriyle tam istihdama ulaşamaz. Ayrıca Keynesyen iktisatçılar eksik istihdamında bir denge olduğunu, devletin maliye politikası araçlarıyla işsizlik sorununa çözüm bulabileceğini savunmuştur. Keynesyen düşünceye göre uygulanacak her politika kısa dönemlidir. Ayrıca Keynes'e göre durgunluk dönemlerinde kamu harcamalarının artırılması çarpan mekanizmasının etkisiyle ekonomide telafi edici etki meydana getirecek ve ekonomi canlanacaktır. Keynesyen iktisat görüşünde, vergilerin sadece kamu harcamalarını finanse eden bir araç olmadığı, aynı zamanda ekonomik büyümenin sağlanması, ekonomik kalkınmanın sağlanması, gelir dağılımda adaletin sağlanması, kaynakların etkin dağılımının sağlanması, ekonomik istikrarın sağlanması ve dış ödemeler dengesinin sağlanması vb. gibi bir çok amaç için önemli bir maliye politikası aracı olduğu görülmektedir. Keynesyen iktisat görüşünde özellikle ekonomik büyümenin sağlanması talep yönlü olarak ele alınmıştır. Söz gelimi, vergileri düşürerek toplam talep seviyesi artırılarak üretim artırılacaktır. Böylelikle firmaların üretim düzeyi artarak yatırım seviyeleri de artacaktır. Yatırım seviyelerinin artmasıyla birlikte ise milli 
gelir düzeyi artacaktır. Bu açıdan ele alındığında milli gelir seviyesinin artması da vergi gelirlerini dolaylı olarak tekrar artıracaktır.

Monetarist teori, Keynesyen düşüncenin maliye politikası hakkındaki görüşlerini eleştirmiştir. Monetaristlere göre 1929 krizinin yaşanmasının nedeni para arzının zamanında ve yeterince artırılamamasıdır. Monetaristlere göre, ekonomi doğası gereği istikrarlıdır. Maliye politikalarının iktisadi dalgalanma dönemlerinde çıktı düzeyi ve istihdam üzerindeki etkisi zayıf olduğu görüşü hakimdir. Bu nedenle, maliye politikalarının çıktı ve istihdam üzerinde olumsuz etki oluşturacağı görüşünü savunmuşlardır. Monetaristler, özellikle 1975 Petrol Krizi'nin yarattığı enflasyonist sürecinin durdurulamaması ile Keynesyen iktisadi görüşe birçok eleştiri getirmişlerdir. Monetaristler temel olarak kamu harcamalarının para basma ve borçlanma ile finanse edildiğini ve enflasyona neden olduğu görüşünü savunmuşlardır. Onlara göre ekonomideki dalgalanmaların nedeni önceden bildirilmeyen ya da etkinsiz para politikaları ve maliye politikalarıdır. Kamu tarafından gerçekleştirilen harcamalar dışlama etkisi meydana getirerek, özel tüketim ve yatıım harcamalarının azalmasına neden olurken, toplam talep, istihdam ve çıktı üzerinde uzun dönemde değişikliğe neden olmayacaktır. Genel olarak politikalarının uzun dönemde istihdam ve çıktı düzeyinde etki yaratmayıp sadece fiyatlar genel seviyesini etkilediğini belirtmektedirler. Vergiler açısından değerlendirildiğinde, monetaristler kamu harcamalarını etkinsiz bir ekonomik değişken gördüklerinden vergilere de aynı bakış açısıyla yaklaşmışlardır.

Arz yönlü iktisatçılar Keynesyen görüşün toplam talep yönlü yaklaşımına tepki göstermiş ve arz koşullarının talepten daha önemli olduğunu savunmuşlardır. Arz yanlı iktisada göre, bütçe denk olmalı ve yatırım ile üretimin teşvik edilebilmesi için vergi oranlarının düşürülmesi gerekmektedir. Artan kamu harcamalarının vergi artışı ile sağlanması, üretim, yatırım ve çalışmanın isteğini azaltacak ve çalışmaya oranla boş zaman daha cazip hale gelecektir. Arz yanlı teorisyenlerce, vergi oranları fiyat düzeyini bozarak üretici tercihlerinin değişmesine neden olacaktır. Arz yanlı iktisatçılar tarafından ortaya koyulan Laffer eğrisine göre vergi oranları ile vergi gelirleri arasında optimum nokta olarak adlandırılan noktaya kadar doğru orantılı bir ilişki söz konusu iken, optimum noktadan sonra vergi oranları ile vergi hasılatı arasında ters orantılı ilişki mevcuttur. Vergi oranlarındaki indirime bireylerin çalışma ve yatırım yapma yönünde vereceği tepkileri ölçmek zordur (Savaş, 1994: 250). Laffer'e göre düşük vergi oranları uzun vadede mükelleflerin gelirlerinde artış yaratarak talebin artmasını sağlayacaktır. Firmalar ise artan talebi karşılamak için üretimi artıracak ve istihdam seviyesinde artış meydana gelecektir. Uygulanan vergi indirimi ile ekonomik büyümeyi olumlu yönde etkileyecektir (Çevik, 2017). Vergiler ve ekonomik büyüme ilişkisi Arz Yanlı İktisat görüşüne göre ele alınırsa, vergi oranları ve dolayısıyla vergi gelirlerinin düşürülmesi öncelikle üretim düzeyini artıracaktır. Çünkü bireyler tüketim yapmak yerine tasarruf edeceklerdir. Böylece boş durma yerine çalışmaya yöneleceklerdir. Bu sayede de vergi gelirleri ve üretim düzeyi artmış olacaktır. Fakat bütün bu varsayımlara rağmen hem monetarist hem de arz yanlı iktisat teorisinde vergilerin uzun dönemde büyüme üzerinde etkisi olmayacağı görüşü yaygındır. 


\section{Literatür}

Ülkelerin vergi yapılarında oluşan değişimlerin ekonomik büyüme üzerinde nasıl bir etki yarattığı uygulanan politikaların etkinliği açısından önemlidir. Bu sayede ekonomik büyüme ve vergi politikaları arasındaki uyum belirlenmektedir. Dolaylı ve dolaysız vergilerin vergi sistemleri içerisindeki oranı, vergilemede etkinlik, tarafsızlık ve adalet vb. aracılığıyla büyüme üzerinde önem arz etmektedir. Ayrıca vergi gelirleri ile ekonomik büyüme arasındaki ilişki uzun yıllardır iktisat literatüründe incelenen bir araştırma alanı olmuştur. Literatürde vergiler ve ekonomik büyüme arasında genel olarak ifade edildiğinde hem negatif hem de pozitif yönlü ilişki koyan çalışmalar mevcuttur. Vergilerin ekonomik büyüme üzerindeki etkisi Solow (1956) tarafından Neo-Klasik büyüme teorisi çerçevesinde ele almıştır. Solow (1956) uzun dönemde büyüme oranının sıfır (sabit) olduğunu bu nedenle ekonomide gerçekleşen büyümenin uygulanan vergi politikalarından etkilenmeyeceğini saptamıştır. Harberger (1964), $A B D$ 'de vergi politikalarının ekonomik büyüme üzerinde etkisiz olduğunu ortaya koymuştur. Marsden (1983), 20 ülke temelinde yapmış olduğu çalışmada vergi oranlarında bir birimlik artışın ekonomik büyümeyi yaklaşık \% 0.36 düzeyinde azalttığını tespit etmiştir. Skinner (1988), vergilerde meydana gelen bir artışın sermaye ve işgücü arzında düşüşe neden olduğunu göstermiştir. Bu durum nedeniyle dolaysız vergi oranlarında meydana gelen bir artış büyüme üzerinde negatif etki meydana getirirken, dış ticaret üzerinden alınan vergi oranlarında meydana gelen bir artış büyüme üzerinde kısıtlı etki oluşturmaktadır. Koester \& Kormendi (1989), Barro (1991), Easterly \& Rebelo (1993), Koch vd. (2005), Poulson \& Kaplan (2008), Gül \& Kenar (2009), Mangır \& Ertuğrul (2012), Organ \& Ergen (2017), Karayılmazlar \& Göde (2017) ve Gürdal \& İnal (2018)'in çalışmalarında vergi oranlarındaki artışın ekonomik büyümeyi azalttığını, vergi oranlarındaki düşüşün ise ekonomik büyümeyi pozitif etkilediğini ortaya koymuşlardır. Literatürde bazı çalışmalar ise vergi gelirlerindeki artışın ekonomik büyümeyi artırdığını ortaya koymaktadır (Stoilova, 2017; Dam \& Ertekin, 2018; Koç, 2019). Bunun yanında bazı çalışmalar ise milli gelir düzeyindeki artışların vergi yükünü veya vergi gelirlerini artırdığını göstermektedir (Çelikay, 2017; Sağdıç, 2019; Yıldız \& Sandalcı, 2019). Literatürde yapılan bazı çalışmaların ise ekonomik büyüme ve vergi gelirleri arasındaki uzun dönemli ilişkileri ortaya koydukları görülmektedir (Kanca \& Yamak, 2018; Akıncı, 2019; Sağdıç vd. 2020).

Literatürde vergi türlerinin ve vergi yapısının ekonomik büyüme ile ilişki içerisinde olduğunu gösteren birçok çalışma mevcuttur. Örneğin, Mendoza vd. (1995) gelir vergisindeki \% 10'luk azalışın yatırımları \%1-2 düzeylerinde artırdığını, harcama vergilerinin ise tam tersi etki gösterdiğini tespit etmişlerdir. Benzer şekilde Kneller vd. (1999), OECD ülkelerini (22) baz alarak 1970 ve 1995 yılları arasındaki dönemde, gelir ve servet vergilerinin ekonomik büyümeyi negatif etkilediğini tespit etmişlerdir. Widmalm (2001), 23 OECD ülkesi verilerini baz alarak gerçekleştirdiği analizinde (19651990) büyüme üzerindeki olumsuz etkilerin ortalama vergi oranlarındaki artıştan ya da tüketim vergilerinde meydana gelen artıştan kaynaklanmadığını tespit etmiştir. Bunun yanında kişisel gelir vergisi ve ekonomik büyüme arasında negatif bir ilişki olduğunu 
tespit etmişlerdir. Branson \& Lovell (2001), 1946-1995 yıllarında Yeni Zelanda ekonomisi için yapmış olduğu çalışmada, vergi yapısının \% 65 dolaysı vergiler \% 35 dolaylı vergiler olarak oluştuğunda ekonomik büyümede \% 17'lik bir artış olduğunu göstermiştir. Lee \& Gordon (2005), seçilmiş 70 ülke için kurumlar vergisi ve ekonomik büyüme arasında negatif yönlü ilişki olduğunu göstermişlerdir. Tosun \& Abizadeh (2005), OECD ülkeleri için (1980-1999), gelir ve servet vergilerinin ekonomik büyümeyi pozitif etkilediğini, sosyal güvenlik vergileri ve harcama vergilerinin ekonomik büyümeyi negatif etkilediğini bulmuşlardır. Johanson vd. (2008), kurumlar, gelir ve harcama vergilerinin ekonomik büyüme üzerinde negatif etkide bulunduklarını tespit etmişlerdir. Arnold (2008), tüketim ve servet vergilerine kıyasla gelir üzerinden alınan vergilerin ekonomik büyümeyi negatif etkilediği olduğu sonucuna ulaşmıştır. Furceri \& Karras (2008), 1965-2007 döneminde 23 ülke için yapmış olduğu çalışmada vergi oranlarındaki artışların ekonomik büyümeyi negatif etkilediğini, sosyal güvenlik vergileri ve harcama üzerinden alınan vergilerin etkisinin gelir vergisine göre daha fazla olduğunu göstermişlerdir. Kuştepeli \& Bilman (2009), Türkiye'de (1975-2004) toplam vergiler, mal ve hizmet vergileri ve gelir vergisinin uzun dönemde ekonomik büyümeyi negatif yönde etkilediğini göstermişlerdir. Veronika \& Lenka (2012) 1998-2010 dönemine ilişkin $A B$ üyesi 27 ülke üzerinde yapmış oldukları çalışmada kurumlar vergisinin ekonomik büyüme üzerinde negatif etkide bulunduğunu göstermişlerdir. Xing (2012), 17 OECD ülkesi için 1970-2004 yılları için yapmış olduğu analizde gelir, kurumlar ve tüketim vergilerinin ekonomik büyüme üzerindeki etkisini negatif, servet vergilerinin etkisini ise pozitif olarak tespit etmiştir. Canavire-Bacarreza vd. (2013), gelir vergisinin ekonomik büyümeyi negatif, tüketim vergisinin ise pozitif etkilediğini tespit etmişlerdir. Gemmel vd. (2014), 1970 ve 2009 yılları arasında 15 OECD ülkesinde gerçekleştirdiği çalışmada kısa dönemde gelir ve kurumlar vergisinde meydana gelen artışın büyüme üzerinde olumsuz etki gösterdiğini belirtmişlerdir. Cural \& Çevik (2015), Türkiye'de (1924-2012) gelir vergileri, servet vergileri ve dış ticaret üzerinden alınan vergilerin ekonomik büyümeyi etkilediğini tespit etmişlerdir.

Ekonomik büyüme, vergi türleri ve vergi sistemlerinin yapısı birbirlerini etkileyen değişkenler olduğu için literatürde bu değişkenler arasında nedensellik ilişkisini belirleyen çalışmalar mevcuttur. Örneğin, Anastassiou \& Dritsaki (2005) Yunanistan için yapmış olduğu çalışmada (1965-2002) ekonomik büyüme ile vergi gelirleri arasında nedensellik ilişkisi tespit etmişlerdir. Benzer şekilde, Mamatzakis (2005), 1960-2003 yılları arasındaki veriler temelinde Yunanistan için yapmış olduğu çalışmada ekonomik büyümenin toplam vergileri ve dolaylı vergileri negatif etkilediğini tespit etmiştir. Yapılan ampirik çalışmalar incelendiğinde, ekonomik büyüme ile dolaylı ve dolaysız vergi değişkenlerinin her ikisi ile çift yönlü nedensellik ilişkisi içerisinde olduklarını gösteren bir çok çalışma olduğu görülmektedir (Temiz, 2008; Açıkgöz, 2008; Ünlükaplan \& Arısoy, 2011; Abdiyeva \& Baygonuşova, 2016; Terzi \& Yurtkuran, 2016; Songur \& Yüksel, 2018; Yıldız \& Sandalcı, 2019). Durkaya ve Ceylan (2006) dolaysız vergiler ve ekonomik büyüme arasında çift yönlü nedensellik, Mucuk \& Alptekin (2008) ise dolaysız vergilerden büyümeye tek yönlü doğru nedensellik tespit etmiştir. Erdoğan vd. (2013), 1998-2011 yılları arasında Türkiye'de dolaylı vergilerden ekonomik büyüme doğru tek yönlü nedensellik tespit etmişlerdir. Bu çalışmaların yanında ekonomik 
büyüme değişkeninden dolaylı ve dolaysız vergilere doğru nedensellik olduğunu tespit eden çalışmalar da mevcuttur (Yavuz \& Beşel, 2015; Eren vd. 2018). Çelikay (2018), 2005-2014 yılları arasında Türkiye'de illerin ekonomik büyüme hızları ve vergi yükü arasında eşbütünleşme ilişkisinin mevcut olduğu saptanmıştır. Kısa dönemde vergi yükündeki \%1'lik artışın ekonomik büyüme hızı üzerinde \%0,6 negatif, uzun dönemde ise $\% 0,9$ pozitif etki ettiğini ortaya koymuştur. Ayrıca vergi yükünden ekonomik büyüme hızına doğru tek yönlü nedensellik olduğu tespit edilmiştir. Altıner \& Çalcalı (2019), Türkiye'de (1961-2017) ekonomik büyümedeki pozitif şoklardan vergi gelirlerindeki pozitif şoklarına tek yönlü nedensellik ilişkisini göstermiştir. Ozpence \& Mercan (2020), Türkiye'de 1970-2018 yılları arasında vergi yükünün ekonomik büyümeyi negatif etkilediğini aynı zamanda değişkenlerin çift yönlü nedensellik ilişkisi içerisinde olduğunu göstermişlerdir.

Ay \& Talaşlı (2008), gerçekleştirdikleri çalışmalarında vergi gelirleri içerisinde az gelişmiş ve gelişmekte olan ülkelerde dolaylı vergilerinin payının daha fazla, gelişmiş ülkelerde ise dolaysız vergilerin payının daha fazla olduğunu ifade etmişlerdir. Göçer vd. (2010), Türkiye'de 1924-2009 yılları arasında dolaylı ve dolaysız vergilerle büyüme arasında anlamlı ve pozitif ilişkinin olduğunu ancak ekonomik büyüme üzerinde dolaysız vergilerin daha etkin olduğunu tespit etmişlerdir. Arısoy \& Kaplan (2010), 1968-2006 yılları arasında Türkiye için yapmış olduğu analizde dolaylı vergiler ve ekonomik büyüme arasında pozitif ilişki tespit etmişlerdir. Saraç (2015), Türkiye'de 1969-2013 yılları arasında yapmış olduğu çalışmada, dolaysız vergilerin ekonomik büyüme üzerindeki etkisini negatif, dolaylı vergilerin ekonomik büyüme üzerindeki etkisini ise pozitif olarak tespit etmişlerdir. Dolaylı ve dolaysız vergiler ile ekonomik büyüme arasındaki ilişkiyi ortaya koyan çalışmalar incelendiğinde, çalışma sonuçlarından elde edilen bulguların dolaylı vergilerin ekonomik büyümeyi pozitif, dolaysız vergilerin ise ekonomik büyümeyi negatif yönde etkilediklerini gösteren sonuçların çoğunlukta olduğu görülmektedir (Topal, 2017; Kızılkaya \& Dağ, 2018; Korkmaz vd., 2019; Topal, 2019). Buna rağmen dolaylı vergilerin ekonomik büyümeyi negatif, dolaysız vergilerin ise ekonomik büyümeyi pozitif yönde etkilediğini gösteren çalışmalara da rastlanılmaktadır (Şaşmaz \& Yayla, 2018; Yılmaz \& Tezcan, 2007). Bunun yanında dolaylı ve dolaysız vergilerin ekonomik aktiviteleri ve dolayısıyla ekonomik büyüme üzerinde olumsuz etki gösterdiğini ortaya koyan çalışmalarda mevcuttur (Demir \& Sever 2017; Karamelikli, 2018; Boğa, 2020). Bütün bu çalışmaların yanında Katırcıoğlu (2010), Umutlu vd., (2011)'in çalışmalarında ekonomik büyüme ve vergiler arasında istatistiki açıdan bir ilişki tespit edilememiştir. Ekonomik büyüme ve vergiler arasındaki ilişkiyi ortaya koyan çalışmalardan bazıları da anket yöntemiyle gerçekleştirilmiştir. Örneğin, Demir vd. (2017), Türkiye genelinde 46 il merkezinde anket yöntemiyle yapmış olduğu çalışmada vergi indirimleri dolayısıyla mükelleflerin \% 43'ü satışlarının arttığını, \% 36,4'ü ise tasarruflarının arttığını belirtmişlerdir. Çalışmada, mükelleflerin vergi indirimleri sonucunda \% 60'nın tasarrufları artıracağını, \% 73'ünün toplam yatırımları artıracağını, \% 67'sinin ise ekonomik büyümeyi artıracağını belirtmişlerdir. 


\section{Veri, Metodoloji ve Ampirik Bulgular}

Türkiye'de 81 il düzeyinde dolaylı-dolaysız vergiler ile ekonomik büyüme arasındaki ilişkinin incelenmesi bu çalışmanın odak noktasıdır. Analiz 2006-2018 yıllarını kapsamaktadır. Dolaylı ve dolaysız vergilerin ekonomik büyüme üzerindeki etkisini analiz etmek amacıyla iki temel model oluşturulmuştur. Her iki modelde bağımlı değişken olarak bölgesel düzeyde kişi başına düşen milli gelir seçilirken, Model 1 'de dolaysız vergilerin toplam vergi gelirlerine oranı, Model 2'de ise dolaylı vergilerin toplam vergi gelirlerine oranı bağımsız değişken olarak seçilmiştir. Modellerde kullanılan tüm değişkenler bölgesel düzeyde olup 81 il düzeyini kapsamaktadır. Araştırmada kullanılan verilerde 2006 yılı sonrası dikkate alınmıştır. Çünkü 2006 yıında 5018 Sayılı Kamu Mali Yönetimi ve Kontrol Kanunu ile Merkezi Yönetim Bütçesi'ne geçilmiştir. Bütçede vergi kalemleri de buna göre değişiklik göstermiştir. Bu yüzden dolaylı ve dolaysız vergiler ile ilgili istatistiklerin 2004 yılından bu yana olmasına rağmen vergi kalemlerindeki uyum nedeniyle bu çalışmada 2006 yılı sonrası dikkate alınmıştır. il düzeyinde dolaylı ve dolaysız vergilere ilişkin veriler Hazine ve Maliye Bakanlığı Muhasebat Genel Müdürlüğü'nün yayınladığı genel yönetim mali istatistiklerinden derlenmiştir. Kişi başına milli gelir düzeyi Türkiye İstatistik Kurumu'ndan alınmıştır. Yapılan analiz ve testler için Eviews 9.0 programı ve Gauss 10 programı kullanılmıştır. Tablo 1'de kullanılan değişkenler, tanımlamaları ve değişkenlerin elde edildiği kaynaklar özetlenmiştir.

Tablo 1: Veri Seti

\begin{tabular}{lll}
\hline \hline \multicolumn{1}{c}{ Değişken } & \multicolumn{1}{c}{ Açıklama } & \multicolumn{1}{c}{ Kaynak } \\
\hline \hline LNRGSYH & Reel kişi başı milli gelir düzeyi & TÜiK \\
\hline LNDZ & $\begin{array}{l}\text { Dolaysız vergi gelirlerinin toplam } \\
\text { vergi gelirlerine oranı }\end{array}$ & HMB, Muhasebat Genel Müdürlüğü \\
\hline DY & $\begin{array}{l}\text { Dolaylı vergi gelirlerinin toplam } \\
\text { vergi gelirlerine oranı }\end{array}$ & HMB, Muhasebat Genel Müdürlüğü \\
\hline \hline
\end{tabular}

Kaynak: Yazarlar tarafından oluşturulmuştur.

Türkiye'de 81 il düzeyinde dolaylı ve dolaysız vergilerin ekonomik büyüme üzerindeki etkisini incelemek amacıyla panel veri analiz yönteminden yararlanılmıştır. Yapılan literatür taramasında, analizlerin vergi yapısını inceleyen çalışmaların nedensellik ve kısa-uzun dönem etkiler üzerinde yoğunlaştığı görülmektedir. Bu amaçla çalışmada, Türkiye'de 2006-2018 yılları arasında il düzeyinde dolaylı ve dolaysız vergilerin ekonomik büyüme üzerinde etkili olup olmadığı yatay kesit bağımlılığını ve modellerdeki homojenliği dikkate alan panel nedensellik ve uzun dönem tahmincileri kullanılarak analiz edilmiştir. Vergi yapısının ekonomik büyüme üzerindeki etkisi dolaylı ve dolaysız verilerin toplam vergi gelirleri içerisindeki payı dikkate alınarak modellere dahil edilmiştir. Dolaylı ve dolaysız vergi gelirlerinin ekonomik büyüme üzerindeki etkisini tahmin etmek amacıyla aşağıda (1) ve (2) numaralı eşitlikteki modeller oluşturulmuştur. 
MODEL 1: $\mathrm{LNGSYH}_{i t}=\beta_{0}+\beta_{1} \mathrm{LNDZ}_{i t}+e_{i t}$

MODEL 2: LNGSYH $_{i t}=\beta_{0}+\beta_{1} \mathrm{DY}_{i t}+e_{i t}$

Model 1, Türkiye'de dolaysız vergilerin il düzeyinde ekonomik büyüme üzerinde etkisinin olup olmadığını tahmin etmek amacıyla oluşturulmuştur. Modelde bağımlı değişken olarak ekonomik büyümeyi LNGSYH temsil ederken, LNDZ ise bağımsız değişken olarak modele dahil edilmiş ve dolaysız vergileri temsil etmektedir. Değişkenler modele doğal logaritmaları alınarak dahil edilmiştir. Model 2, Türkiye'de dolaylı vergilerin ekonomik büyüme üzerindeki etkisini tahmin etmek amacıyla oluşturulmuştur. Modelde LNGSYH kişi başı reel milli gelir düzeyini temsil ederken, DY ise 81 il düzeyinde dolaysız vergileri temsil etmektedir. Türkiye'de il düzeyinde dolaysız vergiler muhtemel KDV iadelerinden dolayı bazı illerde negatif olarak gerçekleşmiştir. Bu yüzden Model 2'de dolaysız vergilerin toplam vergilere oranı logaritmik hale getirilememiştir. Sonuç olarak Model 2, yarı logaritmik olarak tahmin edilmiştir. Araştırmada kullanılan değişkenlerin durağanlık seviyelerinden önce yatay kesit bağımlılıkları Breusch ve Pagan (1980) $C_{\mathrm{LM} 1}$ testi, Pesaran (2004) $\mathrm{CD}_{\mathrm{LM} 2}$ testi, Pesaran (2004) CDLM testi ve Pesaran, Ullah ve Yamagata (2008) $C_{L \text { LMadj }}$ testleri ile tespit edilmiştir. Yatay kesit bağımlılığının tespitinden sonra, değişkenlerin durağanlık seviyeleri yatay kesit bağımlılığına duyarlı ikinci nesil Pesaran CADF (Yatay Kesit Genelleştirilmiş Dickey Fuller) birim kök testi aracılığıyla belirlenmiştir. Değişkenler arasındaki eşbütünleşmenin varlığı Westerlund ve Edgerton LM Bootstrap Eşbütünleşme (2007) testi ile, modeldeki eğim katsayılarının homojenliği ise Pesaran ve Yamagata (2008) Homojenite Testi yardımıyla sınanmıştır. Son aşamada değişkenler arasındaki nedensellik ilişkisi Panel VECM Nedensellik Testi ile incelenmiştir. Değişkenlere ait istatistikler Tablo 2'de özetlenmiştir.

Tablo 2: Tanımlayıcı İstatistikler ve Korelasyon Matrisi

\begin{tabular}{cccc}
\hline \hline & \multicolumn{2}{c}{ Tanımlayıcı İstatistikler } & \\
\hline \hline GSYH & DZ & DY \\
\hline Gözlem Sayısı & 1053 & 1053 & 1053 \\
\hline Ortalama & 16024.73 & 0.588136 & 0.411576 \\
\hline Medyan & 14016.14 & 0.593385 & 0.405489 \\
\hline Std. Sapma & 9036.315 & 0.344438 & 0.344204 \\
\hline Maksimum & 66573.36 & 8.587398 & 0.946072 \\
\hline Minimum & 3051.166 & 0.053647 & -7.587398 \\
\hline \hline Korelasyon Matrisi & & DY \\
\hline \hline LNGSH & 1 & LNDZ & \\
\hline LNDZ & LNGSYH & 1 & 1 \\
\hline DY & -0.2735 & -0.7041 & \\
\hline \hline
\end{tabular}


Türkiye'de dolaylı ve dolaysız vergilerin ekonomik büyüme üzerindeki etkisini analiz etmek amacıyla panel veri analizinden yararlanılmıştır. Panel eşbütünleşme analizi ve Panel VECM nedensellik analizine geçilmeden önce değişkenlerin yatay kesit bağımlılıkları, durağanlıkları, oluşturulan modellerin eşbütünleşme katsayılarının homojenliği ve yatay kesit bağımlılıkları tespit edilmiştir. Panel veri analizinde yatay kesit boyutu zaman boyutundan büyük olduğunda (N>T) Pesaran (2004) $C D_{L M}$ Testi, $(\mathrm{N}>\mathrm{T}$ ve $\mathrm{T}>\mathrm{N}$ ) durumunda ise Pesaran, Ullah ve Yamagata (2008) CDLMadj Testi ile yatay kesit bağımlılığı sınanmaktadır. Zaman boyutu yatay kesit boyutundan büyük olduğunda ise Breusch ve Pagan (1980) $C D_{L M 1}$ Testi Pesaran (2004) $C D_{L M 2}$ Testi ile yatay kesit bağımlılı̆ı tespit edilmektedir. Bu çalışmada yatay kesit boyutu (N) zaman boyutundan ( $T$ ) büyük olduğu için yatay kesit bağımlılığı sonuçları Pesaran (2004) $C D_{L M}$ Testi ve Pesaran, Ullah ve Yamagata (2008) CDLMadj Testi dikkate alınarak yorumlanmıştır. Yatay kesit bağımlık test sonuçları ve durağanlık test sonuçları EK-1'de özetlenmiştir. Test sonuçları değişkenlerinin tümünün yatay kesit bağımlılığı içerdiğini göstermektedir. Çalışmada yatay kesit bağımlılığı tespit edildiği için değişkenlerin durağanlık seviyeleri Pesaran (2007) CADF Testi ile belirlenmiştir. Pesaran CADF Testi, ADF regresyonunun genişletilmiş halini ve gecikmeli yatay kesit ortalamalarını kullandığı için tahmin edilen regresyonun birinci farkında yatay kesit bağımlıı̆̆ını yok etmektedir (Tatoğlu, 2013, s. 223). Diğer bir ifadeyle Yatay Kesit Genelleştirilmiş Dickey Fuller (CADF) olarak adlandırılan bu test yatay kesit bağımlılığını dikkate alan ikinci nesil birim kök testidir. Çalışmada kullanılan değişkenlerde yatay kesit bağımlılı̆ı tespit edildiği için Pesaran CADF testi tercih edilmiştir. EK-2'de özetlenen birim kök test sonuçlarına göre tüm değişkenlerinin birinci farklarında durağan hale geldiklerini göstermektedir. Bunu yanında oluşturulan modellerin yatay kesit bağımlılıkları ve eşbütünleşme eğim katsayılarının homojenlikleri Ek-2'de verilmiştir. Model 1 ve Model 2 için eşbütünleşme denkleminde yatay kesit bağımlığı 0.05 'ten küçük olasılık değerleriyle $\mathrm{H}_{0}$ boş hipotezi reddedilmiştir. Buna göre serilerin yanında modellerde de yatay kesit bağımlılığı olduğu sonucuna varılmıştır. Homojenlik testinde "eğim katsayıları homojendir" şeklindeki $\mathrm{H}_{0}$ hipotezi reddedilerek her iki modelde eğim katsayılarının heterojen olduğuna karar verilmiştir. Modellerde eşbütünleşme ilişkisi bu durumları dikkate alan eşbütünleşme testleri ile tespit edilmelidir. Buradan hareketle modellerdeki eşbütünleşme ilişkisi, hem yatay kesit bağımlılığını hemde katsayıların heterojenliğinde uygulanabilen Westerlund ve Edgerton (2007) LM bootstrap Eşbütünleşme Testi ile sınanmıştır. Lagrange Multiplier test istatistiğine dayanan Westerlund ve Edgerton (2007) LM bootstrap Eşbütünleşme Testinin bir çok avantajı bulunmaktadır. Bunlar eşbütünleşme modelinde yatay kesit bağımlılığına izin vermesi, otokorelasyon ve değişen varyans problemlerini dikkate alması, küçük örneklemlerde etkin sonuçlar verebilmesi olarak belirtilebilir. Test temelinde hesaplanan LM istatistiği ile eşbütünleşme olduğunu belirten $\mathrm{H}_{0}$ hipotezi sınanmaktadır. Eşbütünleşme modelinde yatay kesit bağımlılı̆̆ olduğu durumda bootstrap kiritik değerleri, yatay kesit bağımlılığı olmadığı durumda ise Asimptotik değerler dikkate alınmaktadır. Bu 
çalışmadaki modellerde yatay kesit bağımlılığı tespit edildiği için bootstrap kritik değerleri dikkate alınmıştır. Buna göre, her iki model içinde eşbütünleşme ilişkisinin var olduğunu gösteren $\mathrm{H}_{0}$ hipotezi kabul edilerek modellerde eşbütünleşme ilişkisinin varlığı kabul edilmiştir. Buradan yola çıkılarak Türkiye'de 2006-2018 yılları arasında dolaylı ve dolaysız vergiler ile ekonomik büyüme arasında uzun dönemli ilişki olduğunu tespit edilmiştir.

Tablo 3: LM Bootstrap Eşbütünleşme Testi Sonuçları

\begin{tabular}{cccc}
\hline \hline & İstatistik & Asymptotic p-value & Bootstrap p-value \\
\hline \hline Model 1 & 18.577 & 0.000 & 0.624 \\
\hline Model 2 & 19.372 & 0.000 & 0.628 \\
\hline \hline
\end{tabular}

Not: Boots. Olasılık değerleri 10.000 bootstrap sayısı ile elde edilmiştir.

Türkiye'de düzeyde dolaylı ve dolaysız vergiler ile ekonomik büyüme arasındaki kısa ve uzun dönemli nedensellik ilişkisinin olup olmadığı vektör hata düzeltme modeli temelinde (PANEL VECM) Panel Granger Nedensellik Analizi ile belirlenmiştir. Söz konusu değişkenler arasındaki nedensellik denklemleri (PANEL VECM) Model 1 ve Model 2 olarak aşağıda gösterilmiştir.

MODEL 1: $\Delta \mathrm{LNGSYH}_{i t}=\alpha_{1 i}+\sum_{p=1}^{k} \alpha_{11 i p} \Delta \mathrm{LNGSYH}_{i t-p}+\sum_{p=1}^{k} \alpha_{12 i p} \Delta \mathrm{LNDZ}_{i t-p}+\emptyset_{1 i} E C T_{i t-1}+e_{i t}$

MODEL 2: $\Delta \mathrm{LNGSYH}_{i t}=\alpha_{2 i}+\sum_{p=1}^{k} \alpha_{21 i p} \Delta \mathrm{LNGSYH}_{i t-p}+\sum_{p=1}^{k} \alpha_{22 i p} \Delta \mathrm{DY}_{i t-p}+\emptyset_{2 i} E C T_{i t-1}+e_{i t}$

Eşitlik 3 ve 4'deki Model 1, dolaysız vergiler ile ekonomik büyüme arasındaki kısa ve uzun dönemli nedensellik ilişkisini tahmin etmek amacıyla, Model 2 ise dolaylı vergiler ve ekonomik büyüme arasındaki kısa ve uzun dönemli nedensellik ilişkisini tahmin etmek amacıyla kurulmuştur. Denklemlerde $\mathrm{p}$ gecikme sayılarını, $\Delta$ değişkenlerin birinci fark değerlerini göstermektedir. Denklemlerdeki hata düzeltme terimini temsil eden ECT ise eşbütünleşme denklemlerinden elde edilen kalıntıların bir dönem gecikmeli değerlerini göstermektedir. Modellere ait gecikme uzunluğu Hansen (1982) J testi ile belirlenmiştir. Hansen J testi sonuçları Ek 3'te gösterilmiştir. Test sonuçları her iki modelde de 1 . gecikmenin minimum değerine sahip olduğunu göstermektedir. Bundan dolayı modelin gecikme uzunluğunun 1 olarak tespit edilmiştir. Tahmin edilen eşbütünleşme denklemindeki ECT katsayıları negatif ve istatistiksel olarak anlamlı olduğunda boş hipotez reddedilerek değişkenler arasında uzun dönemli nedensellik olduğu tespit edilmektedir. Modeldeki kısa dönemli nedensellik ilişkisi ise Wald Testi'ne dayalı olarak belirlenmektedir. Wald Testi'ne göre bağımsız değişkenlerin $\mathrm{F}$ istatistiği istatistiksel olarak anlamlı çıktığında, değiş̧kenler arasında kısa dönemli nedensellik ilişkisi olduğu tespit edilmektedir. 
Sağdıç, E.N. \& Aydın, D. (2021). “Dolaylı ve Dolaysız Vergiler ile Ekonomik Büyüme Arasındaki Nedensellik İlişkisi: Türkiye Örneği (2006-2018)”, International Journal of Public Finance, 6(1), 21-46.

Tablo 4: Panel Vektör Hata Düzeltme (VECM) Nedensellik Sonuçları

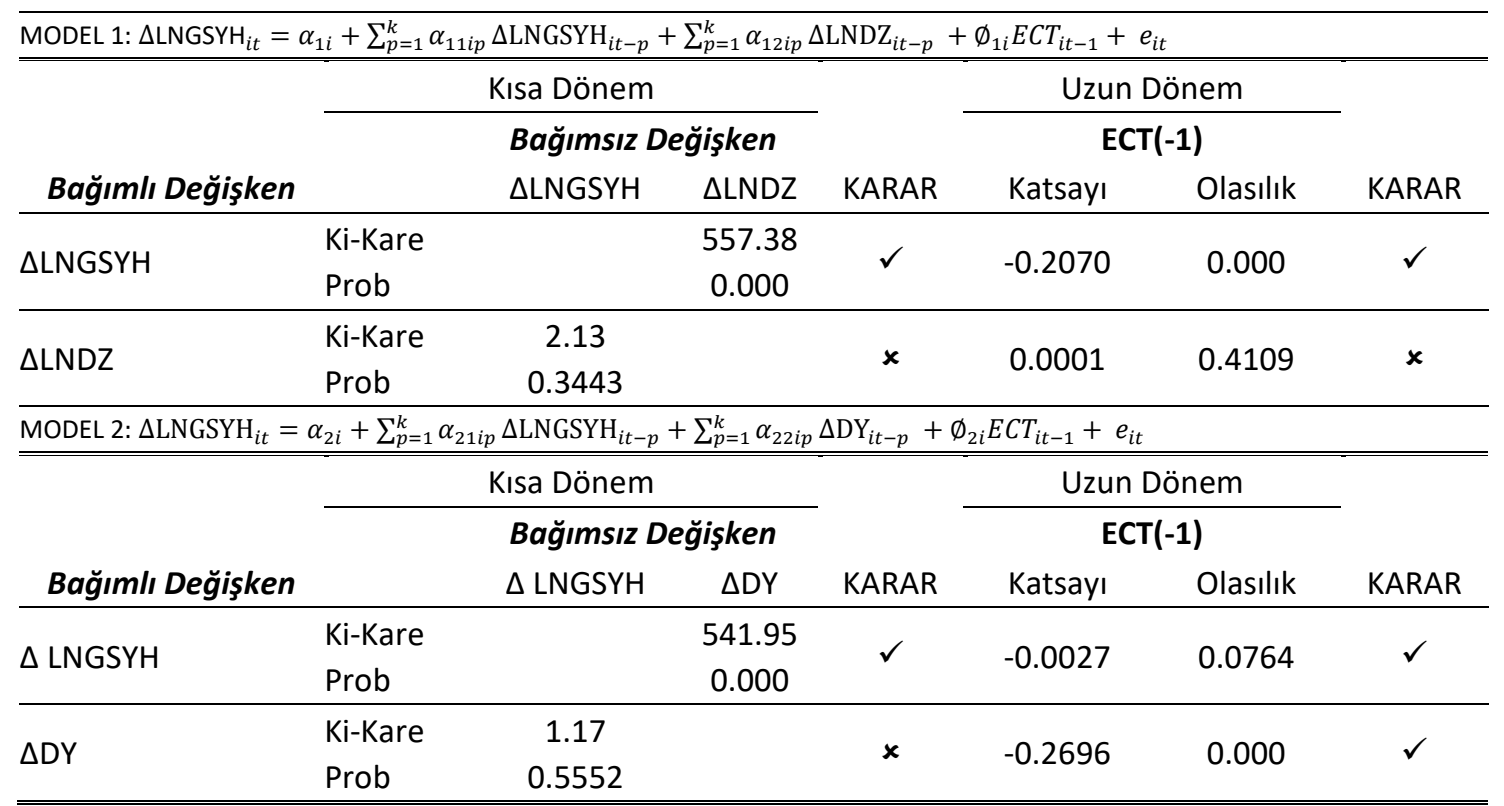

Tablo 4. nedensellik sonuçlarını göstermektedir. Dolaysız vergiler ve ekonomik büyüme arasındaki kısa ve uzun dönemli nedensellik sonuçlarına göre hem kısa dönem hem de uzun dönemde dolaysız vergilerden ekonomik büyümeye doğru tek yönlü nedensellik ilişkisi olduğunu göstermektedir. Ekonomik büyümeden dolaysız vergilere doğru ise nedensellik ilişkisi bulunamamıştır. Model 2, dolaylı vergiler ve ekonomik büyüme arasındaki kısa ve uzun dönemli nedensellik ilişkisini göstermektedir. Panel VECM sonuçlarına göre, Türkiye'de dolaylı vergiler ve ekonomik büyüme arasında uzun dönemde çift yönlü nedensellik ilişkisi vardır. Kısa dönemde ise dolaylı vergilerden ekonomik büyümeye doğru tek yönlü nedensellik ilişkisi tespit edilmiştir. Şekil 1 dolaylı ve dolaysız vergiler ile ekonomik büyüme arasındaki kısa ve uzun dönemli nedensellik sonuçlarını göstermektedir.

Şekil 1: Kısa ve Uzun Dönem Nedensellik ilişkisi

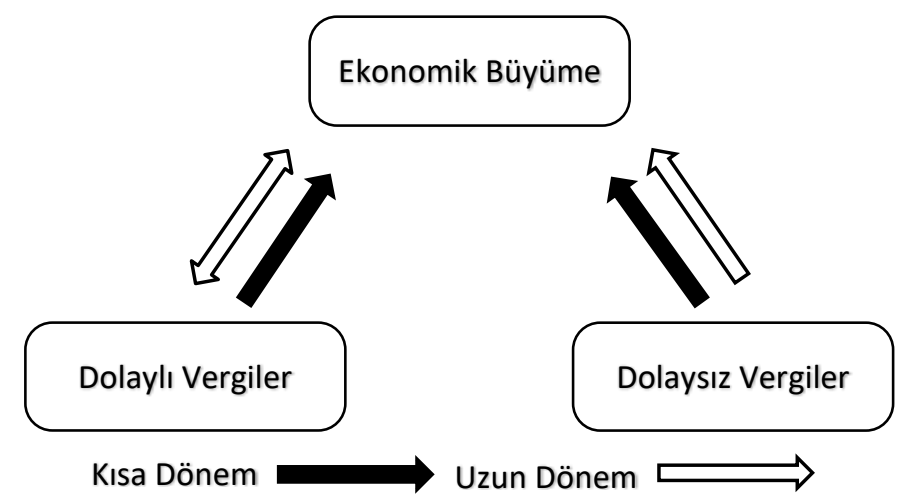


Araştırmanın ampirik sonuçları genel olarak değerlendirildiğinde, Türkiye'de dolaylı ve dolaysız vergiler ile ekonomik büyümenin hem kısa dönem hem de uzun dönemde birbirlerini etkiledikleri tespit edilmiştir. Öncelikle analizde dolaylı ve dolaysız vergilerin uzun dönemde eşbütünleşik olduğu sonucuna varılmıştır. Buradan yola çıkılarak Türkiye'de dolaylı ve dolaysız vergilerin ekonomik büyüme ile uzun dönemde ilişki içerisinde olduğu belirtilebilir. Nedensellik sonuçları hem kısa hem de uzun dönemde dolaysız vergilerden ekonomik büyümeye doğru tek yönlü nedensellik olduğunu göstermiştir. Ekonomik büyümeden dolaysız vergilere doğru bir nedensellik tespit edilememiştir. Dolaylı vergiler ve ekonomik büyüme arasında ise uzun dönemde çift yönlü nedensellik ilişkisi tespit edilirken, kısa dönemde ise dolaylı vergilerden ekonomik büyümeye doğru tek yönlü nedensellik olduğu tespit edilmiştir. Dolaysız vergilerin kısa ve uzun dönemde tek yönlü olarak ekonomik büyüme üzerinde etkili olması iki farklı şekilde gerçekleşebileceği belirtilebilir. Dolaysız vergilerindeki artış durumunda kişilerin kullanılabilir gelirleri ve tasarrufları azalmaktadır. Bu durumda dolaylı olarak yatırımları ve ekonomik büyümeyi etkilemektedir. Dolaylı vergilerin hem kısa hem de uzun dönemde ekonomik büyüme üzerindeki nedensellik etkisi, vergiler nedeniyle gelir etkisinin daha etkin olduğunu göstermektedir. Nedensellik sonuçları dolaylı vergilerin Türkiye'de dolaysız vergilerden daha etkin bir araç olarak kullanıldığını göstermektedir.

\section{Sonuç}

Devlet, toplumda güvenlik ve huzuru sağlama, adaleti tesis etmek, ana faaliyetlerini yürütebilmek ve toplumun ortak ihtiyaçlarını gidermek gibi temel fonksiyonları yerine getirmelidir. Devletin bu fonksiyonları yerine getirirken ihtiyaç duyduğu en temel gelir kaynağı vergilerdir. Vergilerin maliye politikası aracı olarak, bütçe açıkları, borçlanma, yatırım ve tasarruf düzeyi ve istihdam gibi olgularda düzenleyici bir araç olarak kullanılması vergilerin önemini artırmaktadır. Bir ülkede kişi başına düşen milli hasıladaki artış veya gayri safi yurt içi hasılada gerçekleşen artış olarak nitelendirilen ekonomik büyüme uygulanan vergi politikalarıyla yakından ilişkilidir. Ülkelerde uygulanan vergi sistemleri ülkelerin gelişmişlik düzeyine göre farklılık göstermektedir. Dolaylı ve dolaysız vergi olarak tanımlanan vergilerin de ekonomik büyümeyi etkileme kanalları farklılık göstermektedir. Bu nedenle uygulanacak vergi politikalarının büyüme üzerinde etkisinin tespiti önem arz etmektedir. Bu çalışmada dolaylı ve dolaysız vergi gelirlerinin ekonomik büyüme üzerindeki etkileri teorik ve ampirik olarak analiz edilmiştir. Bu amaçla Türkiye' de 20062018 yılları arasında 81 il düzeyinde dolaylı vergi ve dolaysız vergilerin ekonomik büyüme ile ilişkisini belirlemek amacıyla iki ayrı model oluşturulmuştur. Söz konusu ilişkiyi analiz edebilmek için panel veri analizinden yararlanılmıştır. Analiz kısmında öncelikle seriler arasındaki yatay kesit bağımlılı̆̆ incelenmiştir. Araştırmada kullanılan değişkenlerin yatay kesit bağımlılık testleri sonucunda yatay kesit bağımlılıklarının olduğu tespit edilmiştir. Analizin daha sonraki aşamasında değişkenlerin durağanlıkları belirlenerek birinci farklarında durağan oldukları tespit edilmiştir. Eşbütünleşme modellerinin yatay kesit bağımlılıkları ve uzun dönem eğim katsayılarının homojenliği 
belirlendikten sonra modellerde kullanılan değişkenlerin eşbütünleşik olduğu belirlenmiştir. Bu açıdan değerlendirildiğinde, bu çalışma Türkiye'de dolaylı ve dolaysız vergiler ile ekonomik büyümenin uzun dönemli ilişki içerisinde olduğunu göstermektedir. Araştırmanın son aşamasındaki nedensellik test sonuçları, kısa dönemde hem dolaylı vergiler hem de dolaysız vergilerden ekonomik büyümeye doğru tek yönlü nedensellik olduğunu göstermiştir. Uzun dönem nedensellik analizi sonuçları ise dolaysız vergilerden ekonomik büyümeye doğru tek yönlü nedensellik ilişkisi olduğunu, dolaylı vergiler ve ekonomik büyüme arasında çift yönlü nedensellik ilişkisi olduğunu göstermiştir.

Araştırmanın ampirik bulguları genel olarak değerlendirildiğinde hem kısa dönem hem de uzun dönemde dolaylı ve dolaysız vergilerin ekonomik büyüme üzerinde daha etkin olduğu belirtilebilir. Buradan yola çıkılarak Türkiye'de kısa dönemde dolaylı ve dolaysız vergilerin ekonomik büyüme üzerinde etkili olduğu uzun dönemde de bu etkinin kaybolmadığı ve dolaylı vergilerin iktisadi politikalarda daha etkin kullanıldığı tespit edilmiştir. Çelikay (2018) ve Yıldız \& Sandalcı (2019)’nın çalışmalarıyla uyumlu olan sonuçlar hem kısa dönemde hem de uzun dönemde vergilerin ekonomik büyüme sürecine katkıda bulunduğunu göstermektedir. Bu sonuçlara göre Türkiye'de dolaylı ve dolaysız vergilere ilişkin gerçekleştirilecek vergi politikasının ekonomik büyümeye ilişkin politikadan bağımsız şekilde düzenlenemeyeceği ifade edilebilir. Özellikle kurumlar vergisi ve katma değer vergisi gibi vergilerin vergilemede adalet ve verimlilik ilkeleri dikkate alınarak tekrar düzenlenmesi gerekmektedir (Gerçek \&Türegün, 2020). Çelikay (2018)'in de belirttiği gibi toplanan vergi gelirlerinin ekonomik büyüme ve kalkınma dinamikleriyle ilişki içerisinde olması avantaj olarak görülebilir. Ayrıca toplanan vergilerin ekonomik büyümeye katkısının yanında kamu yatırım ve politikalarında etkin olarak kullanılması dışsal olarak ekonomik büyüme ve kalkınmaya katkı sağlayacaktır.

Vergilerin ekonomik büyüme üzerinde etkisi, uzun dönemde ekonomide gerçekleşen büyümenin vergi politikalarından etkilenmeyeceğini varsayan Neo-Klasik büyüme teorisi temelinde Solow (1956) tarafından ele alınmıştır. Solow (1956)'nın öncü çalışması temel alınarak vergilerin ekonomik büyüme üzerindeki etkisi ülke, zaman ve analiz çeşitliliğine bağlı olarak literatürde günümüze kadar ilgi çeken bir araştırma alanı olmuştur. Çalışmalar ülkelerin toplam vergilerinin ekonomik büyüme üzerindeki uzun dönemli ilişkisine yoğunlaşmıştır. Çalışmanın literatür kısmında ayrıntılı olarak belirtildiği gibi vergilerin ekonomik büyüme üzerinde negatif ve pozitif etkileri bir çok çalışmada saptanmıştır. Bunun yanında vergi türleri itibariyle de vergilerin ekonomik büyüme üzerindeki etkisi çalışma alanı bulmuştur. Ayrıca bu çalışmanın da odak noktasını ve amacını oluşturan vergi yapısı itibariyle dolaylı ve dolaysız vergilerin ekonomik büyüme üzerindeki etkileri teorik ve ampirik olarak bir çok çalışmanın temel çalışma alanı haline gelmiştir. Bu çalışma bu itibarla literatüre önemli katkılarda bulunmaktadır. Öncelikle çalışmada büyüme modelleri çerçevesinde vergiler ve ekonomik büyüme arasındaki ilişki ortaya koyulmuştur. Türkiye'de yapılan çalışmalar dikkate alındığında, bu çalışma ile bölgesel düzeyde konunun ele alması ve uzun ve kısa dönem nedensellik sonuçlarını ortaya koyması bakımından ayrıca literatüre katkıda bulunulması hedeflenmiştir. 


\section{Kaynakça}

Abdiyeva, R. \& Baygonuşova, D. (2016). “Geçiş Ekonomilerinde Vergi Gelirleri ve Ekonomik Büyüme İlişkisi:Kırgızistan Örneği”, Akademik Bakış Dergisi, 53, 59-71.

Açıkgöz, Ş. (2008). "Türkiye'de Vergi Gelirleri, Vergi Yapısı ve İktisadi Büyüme İlişkisi: 1968-2006". Ekonomik Yaklaşım Dergisi, 19 (68), 91-113.

Akıncı, A. (2019). "Türkiye'de Vergi Gelirlerinin Ekonomik Büyüme Üzerindeki Etkisi", Finans Ekonomi ve Sosyal Arştırmalar Dergisi, 4 (1), 100-106.

Altıner, A. \& Çalcalı, Ö. (2019). "Türkiye'de Vergi Gelirleri ve Bütçe Harcamalarının Ekonomik Büyüme ile Etkileşimi", Maliye Dergisi, 176, 406-427.

Anastassiou, T. \& Dritsaki, C. (2005), "Tax Revenues and Economic Growth: An Empirical Investigation for Greece Using Causality Analysis", Journal of Social Sciences, 1(2), 99-104.

Arısoy, İ. \& Ünlükaplan, İ. (2010). "Tax Composition and Growth in Turkey: An Empirical Analysis", International Research Journal of Finance and Economics, 59, 50-61.

Arnold, J. (2008). "Do Tax Structures Affect Aggregate Economic Growth? Empirical Evidence from a Panel of OECD Countries", OECD Economic Department Working Papers No. 643.

Ataç, B. (1997). Maliye Politikası, 4. Baskı, Anadolu Üniversitesi Eğitim, Sağlık ve Bilimsel Araştırma Çalışmaları Vakfı Yayınları, Eskişehir.

Ay, H. \& Talaşlı, E. (2008). "Ülkelerin Ekonomik Gelişmişlik Seviyeleri ve Vergi Yapıları Arasındaki îlişki", Maliye Dergisi, 154, 135-155.

Barro, R. (1991). "Economic Growth in a Cross Section of Countries", The Quarterly Journal of Economics, 106 (2), 407-443.

Branson, J., \& Lovell, C. (2001). "A Growth Maximising Tax Structure for New Zelland", International Tax and Public Finance, 8, 129-146.

Breusch, T. S. \& Pagan, A. R. (1980), "The Lagrange Multiplier Test and its Applications to Model Specification in Econometrics.", The Review of Economic Studies, 47(1), 239-253.

Canavire-Bacarreza, G., Martinez-Vazquez, J. \& Vulovic, V. (2013). "Taxation and Economic Growth in Latin America", IDB Working Paper Series No. IDB-WP-431.

Chaudhry, I. S., \& Munir, F. (2010). "Determinants of law tax revenue in pakistan", Pakistan Journal of Social Sciences, 30(2), 439-452. 
Cural, M. \& Çevik K. N. (2015). "Ekonomik Kalkınmanın Vergi Yapısı Üzerindeki Etkisi: 1924-2013 Dönemi Türkiye Örneği”. Amme Idaresi Dergisi, 48 (3), 127-158.

Çelikay, F. (2017). "Milli Gelirin Vergi Yükü Üzerindeki Etkileri: ARDL Sınır Testi Yaklaşımı ile Türkiye Üzerine Bir İnceleme (1924-2014)". Sosyoekonomi, 25 (32), 169-188.

Çelikay, F. (2018). "Vergi Yükünün Ekonomik Büyüme Hızı Üzerindeki Etkileri: Türkiye'deki iller Örnekleminde Amprik Bir Analiz (2005-2014)", iktisadi Idari ve Siyasal Araştırmalar Dergisi, 3 (5), 37-55.

Dam, M. M. \& Ertekin, Ş. (2018). “Türkiye’de Vergi Gelirlerinin Ekonomik Büyüme Üzerindeki Etkisinin Analizi”, Vergi Raporu, 228, 19-32.

Demir, i. C., Cem, G. \& Ciğerci, ì. (2017). “Vergi İndirimlerinin Ekonomik ve Mali Etkileri: Son Dönem Türkiye Uygulamaları", Siyaset, Ekonomi ve Yönetim Araştırmaları Dergisi, 5(5), 75-88.

Demir, M. \& Sever, E. (2017). "Vergi Gelirleri ve Ekonomik Büyüme Iliş̧kisi: OECD Ülkelerine İlişkin Panel Veri Analizi". Aksaray Üniversitesi iktisadi ve Idari Bilimler Fakültesi Dergisi, 9 (2), 51-66.

Demircan, E. S. (2017). "Vergilendirmenin Ekonomik Büyüme ve Kalkınmaya Etkisi", Erciyes Üniversitesi Iktisadi ve Idari Bilimler Fakültesi Dergisi, 21, 97-136.

Durkaya, M. \& Ceylan, S. (2006). "Vergi Gelirleri ve Ekonomik Büyüme”, Maliye Dergisi, 150, 79-89.

Easterly, W. \& Rebelo, S. (1993). "Fiscal Policy and Economic Growth: An Empirical Investigation", NBER Working Paper, 32 (3), 417-458.

Edizdoğan, N. (1981). Teoride ve Uygulamada Özel Tüketim Vergileri, Bursa Üniversitesi Basımevi, Bursa.

Edizdoğan, N. \& Çelikkaya, A. (2012). Vergilerin Ekonomik Analizi, 2. Baskı, Dora Yayınları, Bursa.

Eren, M. V., Ergin Ü. A. \& Aydın, H. ̇̇. (2018). "Türkiye'de Vergi Gelirleri ile Ekonomik Kalkınma Arasındaki İlişki: Frekans Alanı Nedensellik Analizi". Doğuş Üniversitesi Dergisi, 19 (1), 1-18.

Erdoğan, E., Topçu, M. \& Bahar, O. (2013). “Vergi Gelirleri ve Ekonomik Büyüme İlişkisi: Türkiye Ekonomisi Üzerine Eşbütünleşme ve Nedensellik Analizi", Finans Politik \& Ekonomik Yorumlar, 50(576), 99-109.

Eshag, E. (1983). Fiscal and Monetary Policies and Problems in Developing Countries, Cambridge University Press, Cambridge.

Furceri, D., \& Karras, G. (2008). "Tax Changes and Economic Growth: Empirical Evidence for a Panel of OECD Countries", ECB Public Finance Workshop, 1-29. 
Gerçek, A. \& Türegün, F. B. (2020). "Tax System and Tax Reforms in Turkey", Public Financial Management Reforms in Turkey: Progress and Challenges, Volume 1. Accounting, Finance, Sustainability, Governance \& Fraud: Theory and Application, (Eds.) Kral, H. \& Akdemir, T., Springer, Singapore, 3-17.

Gemmell, N., Kneller, R. \& Ismael, S. (2014). "The Growth Effects of Tax Rates in the OECD", Canadian Journal of Economics, 47 (4), 1217-1255.

Göçer, İ., Mercan, M., Bulut, Ş. \& Dam, M. (2010). “Ekonomik Büyüme İle Vergi Gelirleri Arasındaki iliş̧ki: Sınır Testi Yaklaşımı", Dumlupınar Üniversitesi Sosyal Bilimler Dergisi, 28, 97-110.

Gül, E. \& Kenar, B. (2009). “AB Ülkeleri ve Türkiye'de Vergi Gelirleri İle Ekonomik Büyüme İlişkisi". Uluslararası Davraz Kongresi, Bildiriler Kitabı, 16-26, Isparta.

Gupta, A. S. (2007). "Determinants of Tax Revenue Efforts in Developing Countries". IMF Working Paper, 07-184, 1-39.

Hansen, L. P. (1982). Large Sample Properties of Generalized Method of Moments Estimators, Econometrica, 50, 1029-1054.

Harberger, A. (1964). Taxation, Resource Allocation, and Welfare, https://www.nber.org/system/files/chapters/c1873/c1873.pdf, (10.04.2020).

Johanson, O., Heady, C., Arnold, J., B, B., \& Vartia, L. (2008). "Taxand Economic Growth", Economics Department Working Paper No.620, 2-85.

Kanca, O. C. \& Yamak, R. (2018). "Effect of Average Tax Rates on Long-Run Economic Growth Rate in Turkey", ACTA UNIVERSITATIS DANUBIUS, 14 (5), 286-298.

Karamelikli, H. (2018). “Dolaylı ve Dolaysız Vergilerin Ekonomik Aktiviteler Üzerindeki simetrik ve Asimetrik Etkileri", Maliye ve Finans Yazıları, 110, 95-110.

Karayılmazlar, E. \& Göde, B. (2017). "Vergi Yükünün Ekonomik Büyüme Üzerindeki Etkisi", Ömer Halis Demir Üniversitesi iktisadi ve Idari Bilimler Fakültesi Dergisi, 10 (4), 131-142.

Katırcıoğlu, S. (2010). "Is There A Long-Run Relationship Between Taxation and Growth: The Case of Turkey". Romanian Journal of Economic Forecasting, 13 (1), 99-106.

Kibritçioğlu, A. (1998). “iktisadi Büyümenin Belirleyicileri ve Yeni Büyüme Modellerinde Beşeri Sermayenin Yeri", Ankara Üniversitesi Siyasal Bilgiler Fakültesi Dergisi, 53 (1-4), 207-230.

Kızılkaya, F., \& Dağ, M. (2018). Türkiye'de Vergi Gelirleri - Ekonomik Büyüme Ilişsisi: Dönemsel Bir Analiz. Türkiye'de Güncel ve Mali Sorunlar (Ed. Adil Akıncı), IKSAD Publishing House, Ankara.

Kneller, R., Michael F. B., \& Norman, G. (1999). "Fiscal Policy and Growth: Evidence From OECD Countries". Journal of Public Economics, 74 (2), 171-190. 
Koç, Ö. E. (2019). "Türkiye'de Vergi Yükü ve Ekonomik Büyüme iliş̧kisi”. Alanya Akademik Bakış Dergisi, 3(3), 247-259.

Koch, S.F., Schoeman, N. J. \& Van Tonder, J. J. (2005). "Economic Growth and the Structure of Taxes in South Africa: 1960-2002", South African Journal of Economics, 74 (2), 171-190.

Koester, R., \& Kormendi, R. (1989). "Taxation, Aggregate Activity and Economic Growth: Cross-Country Evidence on Some Supply-Side Hypotheses". Economic Inquiry, 27 (3), 367-386.

Korkmaz, S., Yılgör, M. \& Aksoy, F. (2019). "The impact of direct and indirect taxes on the growth of the Turkish economy", Public Sector Economics, 43(3), 311-323.

Kuştepeli, Y. \& Bilman, M. (2009). "Türkiye'de Vergiler ve Büyüme Arasındaki Uzun Dönem Illişkisi", İ̧̧letme Fakültesi Dergisi, 10 (1), 119-130.

Lee, Y. \& Gordon, R.H. (2005). "Tax Structure and Economic Growth", Journal of Public Economics, 89(5), 1027-1043.

Lucas, R. (1988). "On the Mechanics of Economic Development", Journal of Monetary Economics, 22 (1), 3-42.

Mangır, F. \& Ertuğrul, H. M. (2012). "Vergi Yükü ve Ekonomik Büyüme İlişkisi: 19882011 Türkiye Örneği", Maliye Dergisi, 162, 256-265.

Mamatzakis, E.C. (2005). "The dynamic responses of growth to tax structure for Greece", Applied Economics Letters, 12(3), 177-180.

Marsden, K. (1983). "Links between Taxes and Economic Growth: Some Empirical Evidence", World Bank Staff Working Papers, 605.

Mendoza, E. G., Gian. M. M. \& Patrick, A. (1997). "On the Ineffectiveness of Tax Policy in Altering Long-Run Growth: Harberger's Superneutrality Conjecture", Journal of Public Economics, 66 (1), 99-126.

Mucuk, M. \& Alptekin, V. (2008). “Türkiye'de Vergi ve Ekonomik Büyüme illişkisi: VAR Analizi (1975 - 2006)", Maliye Dergisi, 155, 159-174.

Organ, İ. \& Ergen, E. (2017). "Türkiye'de Vergi Yükünün Ekonomik Büyümeye Etkileri Üzerine Bir Çalışma", Pamukkale Üniversitesi Sosyal Bilimler Enstitüsü Dergisi, 27, 197-207.

Ozpence, O. \& Mercan, N. (2020), "The Relationship Between Tax Burden and Economic Growth: Turkey Case", Journal of Business, Economics and Finance, 9(2), 143-154.

Pesaran, M. H. (2004). "General Diagnostic Tests for Cross Section Dependence in Panels", Cambridge University Working Paper, 0435, 1-39. 
Pesaran, M. H. (2007), "A Simple Panel Unit Root Test in the Presence of Cross-Section Dependence", Journal of Applied Econometrics, 2(2), 265-312.

Pesaran, M. H., Ullah, A. Yamagata, T. (2008). "A Bias-Adjusted LM Test of Error CrossSection Independence.", The Econometrics Journal, 11(1), 105-127.

Pesaran, M. H. \& Takashi, Y. (2008). "Testing slope homogeneity in large panels", Journal of Econometrics, 142, 50-93.

Poulson, B., \& Kaplan, J. (2008). "State Income Taxes and Economic Growth", The CATO Journal, 28), 53-71.

Romer, P. (1994). "The Origins of Endogenous Growth", Journal of Economic Perspectives, 8 (1), 3-22.

Sağdıç, E. N. (2019). "Vergi Gelirlerini Belirleyen Faktörlerin Bölgesel Analizi: Türkiye Örneği", Dumlupınar Üniversitesi Sosyal Bilimler Enstitüsü Dergisi, 60, 155-178.

Sağdıç, E. N., Yıldız, F. \& Sayın, H. H. (2020). “Doğrudan Yabancı Yatırımlar, Vergi Gelirleri ve Ekonomik Büyüme illişkisi: Kırılgan Beşli Ülkeler Örneği”, Süleyman Demirel Üniversitesi Vizyoner Dergisi, 11(28), 680-699.

Saraç, T. B. (2015), "Vergi Yükü ve Ekonomik Büyüme illişkisi: Türkiye Örneği", Maliye Dergisi, 169, 21-35.

Savaş, V. F. (1994). Politik iktisat, Beta Yayınevi, İstanbul.

Skinner, J. (1988). "Taxation and Output Growth in Africa. International Economics Department", World Bank Working Paper Series, No: 73.

Solow, R. M. (1956). "A Contribution to the Theory of Economic Growth", Quarterly Journal of Economics, 70, 65-94.

Songur, M. \& Yüksel, C. (2018). "Vergi Yapısı ile Ekonomik Büyüme Arasındaki Nedensellik İlişkisi: Türkiye Örneği". Finans Politik \& Ekonomik Yorumlar, 643, 47-70.

Stoilova, D. (2017). "Tax structure and economic growth: Evidence from the European Union", Contadurıa y Administracion, 62), 1041-1057.

Şaşmaz, M., \& Yayla, Y. (2018). “Doğrudan Yabancı Sermaye Yatrırımlarının Ekonomik Kalkınma Üzerindeki Etkisi: OECD Ülkeleri Örneği”. Hitit Üniversitesi Sosyal Bilimler Enstitüsü Dergisi, 11 (1), 359-374.

Takım, A. (2011). “Türkiye'de 1960-1980 Yılları Arasında Uygulanan Kalkınma Planlarında Maliye Politikaları", Maliye Dergisi, 160), 154-176.

Temiz, D. (2008). "Türkiye'de Vergi Gelirleri ve Ekonomik Büyüme iliş̧kisi". 2. Ulusal iktisat Kongresi, 20-22 Şubat 2008, İzmir.

Terzi, H. \& Yurtkuran, S. (2016). "Türkiye'de Dolaylı/Dolaysız Vergi Gelirleri ve GSYH İlişkisi". Maliye Dergisi, 171, 1-19. 
Topal, M. H. (2017). "Vergi Yapısının Ekonomik Büyüme Üzerindeki Etkisi: OECD Ülkelerinden Ampirik Bir Kanıt", Siyaset, Ekonomi ve Yönetim Araştırmaları Dergisi, 5 (3), 183-206.

Topal, M. H. (2019). "An Analysis of The Relationship Between Tax Structure and Gross Domestic Product in European Transition Economies", JETAS, 7 (2), 183-206.

Tosun, M. \& Abizadeh, S. (2005). "Economic Growth and Tax Components: An Analysis of tax Changes in OECD", Applied Economics, 37, 2251-2263.

Tümer, Ö. (2012). "Stratejik planlamaya dayalı performans esaslı bütçeleme öncesi ve sonrası vergi gelirleri, ekonomik büyüme ilişkisi", Yüksek Lisans Tezi, Pamukkale Üniversitesi Sosyal Bilimler Enstitüsü, Denizli.

Uluatam, Ö. (2012). Kamu Maliyesi, 12.Baskı, İmaj Yayınları, Ankara.

Umutlu, G., Alizadeh, N. \& Erkılıç, A. Y. (2011). "Maliye Politikası Araçlarından Borçlanma ve Vergilerin Ekonomik Büyümeye Etkileri". Uludağ Üniversitesi iktisadi ve Idari Bilimler Fakültesi Dergisi, 1, 75-93.

Ünlükaplan, í. \& Arısoy, ì. (2011). “Vergi Yükü ve Yapısı İle İktisadi Büyüme Arasındaki Dinamik Etkileşimler Üzerine Uygulamalı Bir Analiz". ODTÜ Gelişme Dergisi, (38), 71-100.

Westerlund, J. \& David L. E. (2007). "A panel bootstrap cointegration test", Economics Letters, 97, 185-190.

Widmalm, F. (2001). "Tax Structure and Growth: Are Some Taxes Better than Others?", Public Choice, 107(3/4), 199-219.

Veronika, B., \& Lenka, J. (2012). "Taxation of Corporations and Their Impact on Economic Growth: The Case of EU Countries". Journal of Competitiveness, 4 (4), 96-108.

Xing, J. (2012). "Tax Structure and Growth: How Robust is The Empirical Evidence?", Economics Letters, 117 (1), 379-382.

Yavuz, H. \& Beşel, H. (2015). “Türkiye'de Uluslararası Ticaret ve Muamelelerden Alınan Vergi Gelirleri - Ekonomik Büyüme İlişkisi: Frekans Nedensellik Analizi”. Siyaset, Ekonomi ve Yönetim Araştırmaları Dergisi, 3 (1), 45-55.

Yıldız, F. \& Sandalcı, U. (2019). "Vergi Yapısı ve Ekonomik Büyüme Arasındaki Nedensellik İlişkisi:Türkiye'de iller Düzeyinde Ampirik Bir Analiz (2004-2014)", Vergi Dünyası, 1 (452), 20-34.

Yılmaz, F. \& Tezcan, N. (2007). "Vergi Hasılatı ve Sabit Sermaye Yatırımlarının Ekonomik Büyümeye Olan Etkisi: Ekonometrik Bir İnceleme", 8. Türkiye Ekonometri ve Istatistik Kongresi, 24-25 Mayıs 2007, Malatya. 
Sağdıç, E.N. \& Aydın, D. (2021). “Dolaylı ve Dolaysız Vergiler ile Ekonomik Büyüme Arasındaki Nedensellik ilişkisi: Türkiye Örneği (2006-2018)”, International Journal of Public Finance, 6(1), 21-46.

\section{EKLER}

\section{EK -1: Yatay Kesit Bağımlılığı ve Birim Kök Test Sonuçları}

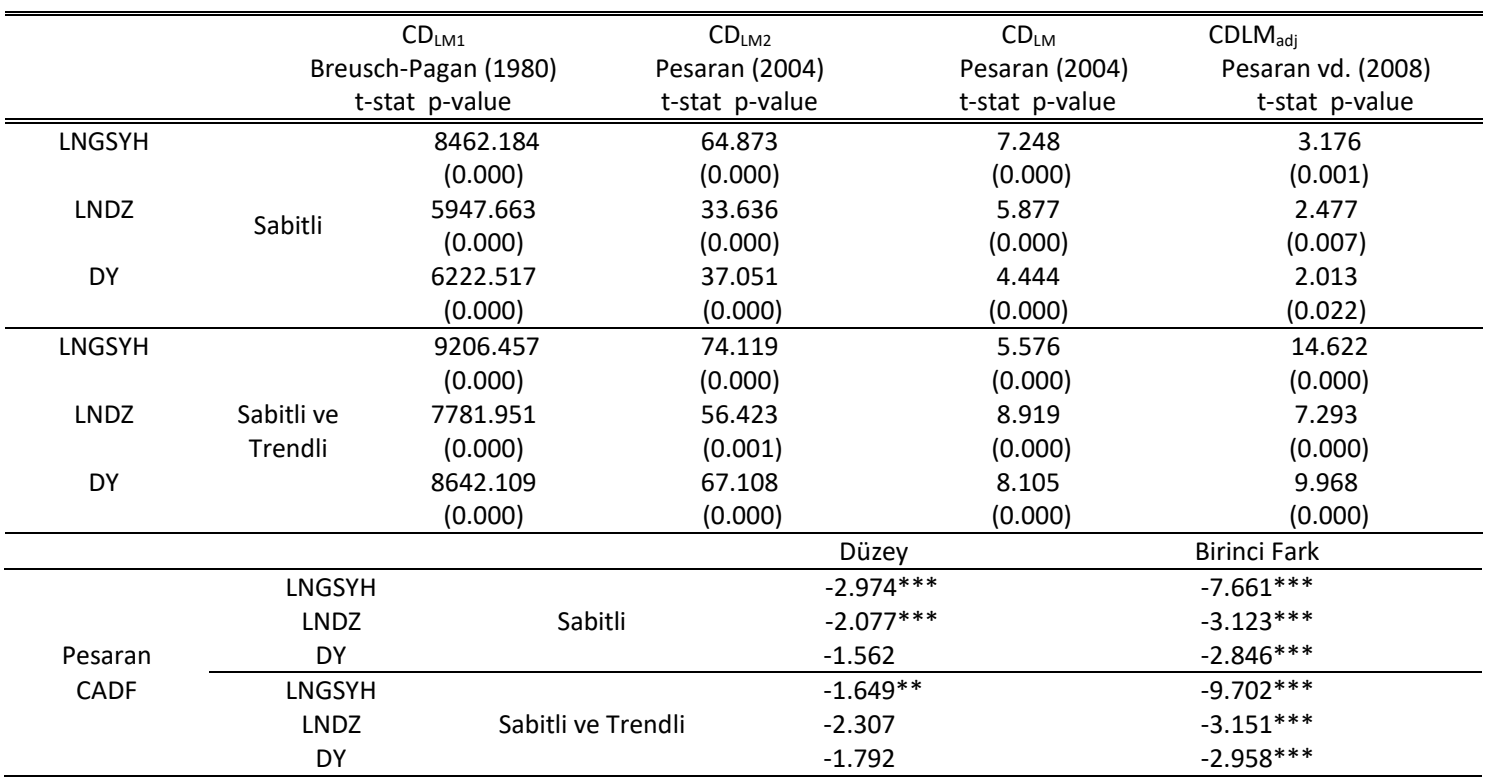

Not: ${ }^{* * *}, * *, *$ sıfır hipotezinin sırasıyla $\% 10, \% 5$ ve \%1 anlamlılık düzeyinde reddedildiğini göstermektedir. Panel istatistiği, CADF istatistiklerinin ortalamasıdır.

Ek -2: Yatay Kesit Bağımlılığı ve Homojenlik Testleri

\begin{tabular}{|c|c|c|c|}
\hline \multicolumn{4}{|c|}{ MODEL 1: LNGSYH $_{i t}=\beta 0+\beta 1$ LNDZ $_{i t}+e_{i t}$} \\
\hline & & İstatistik & p-değeri \\
\hline \multirow{3}{*}{ Yatay Kesit Bağımlılığı } & $\mathrm{CD}_{\mathrm{LM} 1}$ & 6927.327 & 0.000 \\
\hline & $\mathrm{CD}_{\mathrm{LM} 2}$ & 45.806 & 0.000 \\
\hline & CDLM $_{-A D J}$ & 37.239 & 0.000 \\
\hline \multirow{2}{*}{ Homojenlik } & Delta Tilde & 6.189 & 0.000 \\
\hline & Delta Tilde adj & 7.056 & 0.000 \\
\hline \multicolumn{4}{|c|}{$\begin{array}{c}\text { MODEL 2: } \text { LNGSYH }_{\text {it }}=\beta 0+\beta 1 \text { DY }_{\text {it }}+\mathrm{e}_{\text {it }} \\
\end{array}$} \\
\hline & & İstatistik & p-değeri \\
\hline \multirow{3}{*}{ Yatay Kesit Bağımlılığı } & $\mathrm{CD}_{\mathrm{LM} 1}$ & 6628.768 & 0.000 \\
\hline & $\mathrm{CD}_{\mathrm{LM} 2}$ & 42.097 & 0.000 \\
\hline & $\mathrm{CDLM}_{-\mathrm{ADJ}}$ & 35.112 & 0.000 \\
\hline \multirow{2}{*}{ Homojenlik } & Delta Tilde & 6.068 & 0.000 \\
\hline & Delta Tilde adj & 6.918 & 0.000 \\
\hline
\end{tabular}

Ek -3: Gecikme Uzunluğu Tahmin Sonuçları

\begin{tabular}{|c|c|c|c|c|c|c|}
\hline \multicolumn{7}{|c|}{ Model 1} \\
\hline Lag & $C D$ & J & J pvalue & $\mathrm{MBIC}$ & MAIC & MQIC \\
\hline 1 & 0.999139 & 89.59954 & $1.60 \mathrm{E}-18$ & 24.15127 & 81.59954 & 66.51515 \\
\hline 2 & 0.999548 & 127.7335 & $3.25 \mathrm{E}-18$ & 33.65512 & 83.1819 & 67.96465 \\
\hline 3 & 0.9995652 & 99.1819 & $6.27 \mathrm{E}-18$ & 47.39078 & 83.1819 & 69.29747 \\
\hline 4 & 0.9995911 & 111.3418 & $1.77 \mathrm{E}-19$ & 63.70398 & 95.73352 & 74.65733 \\
\hline \multicolumn{7}{|c|}{ Model 2} \\
\hline Lag & $C D$ & J & J pvalue & $\mathrm{MBIC}$ & MAIC & MQIC \\
\hline 1 & 0.9946889 & 81.40825 & $8.76 \mathrm{E}-17$ & 18.95539 & 73.40825 & 57.72487 \\
\hline 2 & 0.9966277 & 102.5515 & $7.95 \mathrm{E}-18$ & 24.86483 & 82.67723 & 62.76877 \\
\hline 3 & 0.9963506 & 98.67723 & $1.76 \mathrm{E}-16$ & 46.88611 & 78.55152 & 66.46603 \\
\hline 4 & 0.9964605 & 122.5376 & $1.78 \mathrm{E}-18$ & 55.51268 & 90.53764 & 68.7928 \\
\hline
\end{tabular}

